\title{
Do high-skill immigrants raise productivity? Evidence from Israeli manufacturing firms, 1990-1999
}

\author{
M Daniele Paserman ${ }^{1,2,3,4,5}$
}

Correspondence: paserman@bu.edu ${ }^{1}$ Boston University, Boston, USA

${ }^{2}$ NBER, Cambridge, USA

Full list of author information is available at the end of the article

\begin{abstract}
This paper exploits the episode provided by the mass migration from the former Soviet Union to Israel in the 1990s to study the effect high skill immigration on productivity. Using a unique data set on manufacturing firms, I investigate directly whether firms and industries with a higher concentration of immigrants experienced increases in productivity. The analysis finds no correlation between immigrant concentration and productivity at the firm level in cross-sectional and pooled regressions. First-differences estimates reveal, if anything, a negative correlation between the change in output per worker and the change in the immigrant share. The immigrant share was strongly negatively correlated with productivity in low-tech industries. In high-technology industries, the results point to a positive relationship, hinting at complementarities between technology and the skilled immigrant workforce.
\end{abstract}

JEL codes: J61, F22, D24

Keywords: Immigration, Productivity

\section{Introduction}

The last twenty years have seen an increase in the share of highly skilled immigrants in many OECD countries (Chaloff and Lemaitre, 2009). At the same time, many countries are promoting or actively considering policies aimed at encouraging further highskilled migration. The rationale for these policies is that highly skilled immigrants may boost innovation (Hunt and Gauthier-Loiselle, 2010); create jobs for native workers (Zavodny, 2011); induce natives to specialize in jobs in which they have a comparative advantage (Peri and Sparber, 2009); or perhaps it is simply necessary to "import" migrant workers to address labor shortages in specific sectors.

However, it is not unambiguously clear that highly skilled immigrants would necessarily boost productivity. First, human capital acquired abroad may not be entirely transferable to the host economy (Friedberg, 2000), possibly because immigrants have weak language skills that reduce their productivity (Bleakley and Chin, 2004). Second, the absorption of even high-skilled immigrants may require some vocational training (either private or government-sponsored, Cohen-Goldner and Eckstein, 2010), which may depress productivity, at least in the short run. Finally, it is not obvious that the positive association between high skilled immigration and outcomes observed in cross-sectional data, at current levels of immigration, will necessarily carry over if migration policy were to be changed in a way that would substantially increase the influx of high-skilled workers.

(c) 2013 Paserman; licensee Springer. This is an Open Access article distributed under the terms of the Creative Commons Attribution License (http://creativecommons.org/licenses/by/2.0), which permits unrestricted use, distribution, and reproduction in any medium, provided the original work is properly cited. 
In this paper, I investigate whether a large and sudden influx of high-skilled workers increases productivity, exploiting the unique episode provided by the mass migration from the Former Soviet Union (FSU) to Israel during the 1990s. From the last quarter of 1989 until 2001, over 1 million immigrants from the Former Soviet Union (FSU) arrived in Israel, increasing its population and labor force by extraordinary rates. At the peak of the immigration wave in 1990 and 1991, over 330 thousand FSU Jews immigrated to Israel, increasing Israel's potential labor force by 8 percent and its population by 15 percent. In addition to its size, another unique aspect of this immigration wave is that many of the immigrants were highly educated. About 60 percent of the FSU immigrants who arrived between 1989-1990 were college-educated and almost one-fourth were college graduates. In contrast, only about 30 percent of the native Israeli Jews in 1990 were college educated, and 12 percent were college graduates.

I use a unique data set on Israeli manufacturing firms and investigate directly whether firms and industries with a higher concentration of immigrants experienced increases in productivity. The analysis is carried out by running conventional production function regressions, where the share of immigrants is treated as an additional right hand side variable. This econometric specification is obtained directly from microeconomic principles if one assumes a Cobb-Douglas production function, perfect substitutability between native and immigrant labor, and possible differences in the efficiency units of labor provided by native and immigrant workers. The coefficient on the share of immigrants will be positive if immigrant workers are more productive (because they are more educated, innovative, inherently more hard-working, or other reasons) and negative if immigrants are less productive (because of language barriers, low transferability of human capital, or other reasons). Thus, the model directly nests the two competing theories about the effect of high-skill immigration on productivity.

The analysis reveals a number of interesting results. First, despite their high levels of formal education, immigrants were initially employed in low-skill occupations, and moved up the occupational ladder only a number of years after arrival. This is consistent with evidence from other studies that used individual-level data (Weiss et al., 2003; Eckstein and Weiss, 2002 and 2004). Second, a firm's immigrant share in 1993, shortly after the peak of the immigration wave, can be predicted by a number of preimmigration firm characteristics: firms that in 1990 had a high capital/labor ratio, paid low wages and were in industries with a low-educated workforce employed a relatively high share of immigrants. By 1997, many of these correlations were weakened or reversed. Third, in cross-sectional and pooled OLS production function regressions, I find no evidence that the immigrant share is correlated with productivity. Firstdifferences estimates reveal, if anything, a negative correlation between the change in output per worker and the change in the immigrant share. Fourth, the immigrant share was strongly negatively correlated with productivity in low-tech industries. In high-tech industries, the results are somewhat mixed, but tend to point to a positive relationship, hinting at complementarities between technology and the skilled immigrant workforce.

One potential shortcoming with this analysis is that immigrants do not sort themselves across firms randomly, casting doubt on whether the coefficients can be given a causal interpretation. While this is a legitimate concern, it should also not be exaggerated. First, the first evidence points to little or no relationship between the share of immigrants in a firm in 1993 and pre-immigration productivity levels. Second, I can 
supplement the firm-level analysis with an industry-level analysis, which makes it possible to address the potential endogeneity of the key right-hand-side variable using an instrumental variable strategy. The instrument for the actual immigrant share is the immigrant share predicted solely by the total number of immigrants in the post-1989 period and the distribution of immigrants across industries in 1983. This industry-level analysis also allows me to investigate whether there were any knowledge spillovers at the industry level. Both the OLS and IV results confirm the findings of the firm-level analysis, namely that there is no evidence of a productivity-enhancing effect of immigration. Finally, even if the concerns about endogeneity are not completely assuaged, the relationship between immigration (and high-skill immigration in particular) and productivity has received so little attention in the literature, that even a purely descriptive/correlational analysis represents an important contribution to our knowledge.

The rest of the paper is structured as follows: the next Section connects the paper to the existing literature on immigration and productivity, and other related areas. Section 3 presents some general macroeconomic trends in the Israeli economy between 1970 and 1999, and in the manufacturing sector in particular. Section 4 describes the data. Section 5 discusses the distribution of immigrants across firms and industries in 1993 and 1997. Section 6 presents the basic estimates of the production function, as well as additional robustness tests and specification tests. Section 7 concludes.

\section{Literature review}

The paper makes contributions to five different strands of literature. First, it is one of the first studies to look directly at the relationship between immigration and productivity. Using state-level data from the United States, Quispe-Agnoli and Zavodny (2002) find that labor productivity increased more slowly in states that attracted a larger share of immigrants in the 1980s, both in low-skill and high-skill industries; on the other hand, Peri (2012), also using U.S. data, but focusing more on the long-run impact, finds that immigration had a strong positive association with total factor productivity and a negative association with the high skill-bias of production technologies. Studies from other countries have also reached contrasting conclusions: Kangasniemi et al. (2012) find that immigration made a negative contribution to labor productivity growth in Spain, and a negative but negligible contribution in the UK, as well as mixed effects on total factor productivity. Huber et al. (2010) analyze productivity at the sectoral level in 12 EU countries, and find little evidence to suggest that migrants on the whole have raised productivity, although high-skilled migrants do appear to play a positive role in productivity developments in skill-intensive industries. The current study arguably improves on the existing literature because of the focus on high skill immigration, and because it exploits information on immigrant concentration at the firm level, a unique feature of my data set.

Second, this paper joins the growing the literature that attempts to understand how firms and industries respond to migration waves. Lewis (2003) finds that relative labor supply shocks have little effect on the local industry mix; instead, industries respond to these shocks by changing their relative factor intensities. Lewis (2011) further corroborates these findings by showing that in markets with a higher availability of less-skilled labor, manufacturing plants are less likely to introduce automated production techniques. Lewis argues that these endogenous changes in production techniques may 
explain why wages of unskilled workers have been found not to respond to large immigration-induced labor supply shocks. Gandal, Hanson and Slaughter (2004) obtain similar results in the Israeli context: they find that global changes in production techniques were sufficient to more than offset Israel's change in relative factor supplies induced by the Soviet immigration, while changes in output mix did not help Israel absorb changes in relative factor prices. These studies, however, did not have micro data on the distribution of immigrants across establishments, and therefore could not investigate directly the effect of immigrants on plant productivity.

Third, the paper contributes to our understanding of the effects of immigration on the host economy's labor market. Much of the previous work on the impact of immigration on the host economy's labor market has found that wages are only mildly negatively affected by the influx of competing workers ${ }^{1}$. This suggests that offsetting flows of labor or capital, or improvements in firms' productivity must occur in order for native wages to maintain their pre-immigration level. This last scenario could well be plausible in the Israeli case, because of the high skill content of the immigrant population. Indeed, the aggregate data reveal that the manufacturing sector, which employed a disproportionate share of FSU immigrants, experienced sustained growth in output per worker and total factor productivity during the 1990s. While it is possible that this was simply part of the global trend of faster productivity growth in manufacturing, ${ }^{2}$ it is worth investigating whether the high-skilled immigration may have also made a contribution.

Fourth, the paper is related to the literature on the effects of a highly educated workforce on labor productivity. Moretti (2004) finds robust evidence of educational spillovers in U.S. manufacturing: the productivity of plants in cities that experience large increases in the share of college graduates rises more than the productivity of similar plants in cities that experience small increases in the share of college graduates. Exploiting the longitudinal nature of his data, Moretti can address the most relevant endogeneity and selectivity issues by including plant and city fixed effects: however, his data cannot conclusively rule out the possibility that time-varying productivity shocks are correlated with changes in the overall level of human capital in a city. One advantage of my study is that it allows me to investigate the productivity effects of the large, unexpected, and arguably exogenous shock to the stock of human capital represented by the Soviet immigration to Israel ${ }^{3}$.

Finally, the paper helps us to understand the determinants of growth in the Israeli economy in the 1990s. Hercowitz (2002), and Hercowitz, Lavi and Melnick (1999), using macroeconomic time series data up to 1995, find that immigration has a negative short-run impact on TFP growth. They interpret these results as a consequence of the immigrants' slow process of adjustment to the labor market, implicitly arguing that TFP should have picked up once the adjustment process had been completed. My paper sheds light on this issue by extending the analysis to the end of the decade: this is a particularly interesting period of analysis, because by this time the most difficult part of the immigrants' adjustment process had already been completed, and because the Israeli economy experienced a surge in productivity growth in the second half of the 1990s.

\section{Israeli productivity, 1970-1999: macroeconomic trends}

Table 1 presents the average yearly growth rates in total output per worker and in total factor productivity, by decade, between 1970 and $1999^{4}$. Output per worker and total factor productivity grew at a sustained and similar rate during the 1970s, but growth 
slowed down considerably during the 1980s. In the 1990s, the growth rate picked up again, with the manufacturing sector leading the charge in both output per worker and TFP. Figure 1 presents the evolution of output per worker for the entire Israeli economy and for the manufacturing sector alone, between 1970 and 2000. The two series grew at fairly similar rates between 1970 and 1993, but since then manufacturing output per worker has taken off at a fast rate, while overall output per worker has remained essentially constant. Figure 2 illustrates that much of the 1990s growth in the manufacturing sector was concentrated in high and medium-high technology industries, even though low and medium-low tech industries also experienced growth in the latter part of the decade ${ }^{5}$.

At the same time, many of the post-1989 immigrants $^{6}$ found employment in the manufacturing sector, as can be seen by Table 2, which is based on data from the Israeli Labor Force Surveys between 1990 and 1999: ${ }^{7}$ throughout the decade, the share of immigrants in manufacturing was nearly double that of natives. Given the high level of educational attainment of immigrants (and in particular the high concentration of engineers), ${ }^{8}$ it is natural to think that there may be a causal link between immigrant employment and growth in the manufacturing sector.

Figure 3 presents the decomposition of manufacturing output in the 1990s into its components: value added per worker, labor, capital per worker, ${ }^{9}$ and total factor productivity. We see that labor input increased sharply in the first part of the decade, and then remained fairly constant in the second part. The mirror image of this trend can be seen in the evolution of capital per worker: it dropped by about 10 percent between 1990 and 1992, before rebounding to its initial level by 1995, and then growing very quickly in the second part of the decade. This matches the prediction of a simple economic model in which the capital stock is fixed in the short run, but can adjust in the long run in response to immigration, to take advantage of the higher marginal productivity that arises following the influx of workers ${ }^{10}$. Both value added per worker and TFP fluctuated in the first part of the decade, and then began to grow steadily since 1995.

Figure 4 also shows that the manufacturing sector experienced skill upgrading during the 1990s. The proportion of workers with high education (some college or more) rose steadily throughout the decade, from about 26 percent in 1990 to 43 percent in 1999. This may reflect the growing share of immigrants with high education in manufacturing employment, but also the increasing educational attainment of the non-immigrant workforce. When measuring skill by the proportion of workers in white-collar occupations, we see a slightly different picture: the share of white collar workers fell in the first part of the decade (from about 21 to 19 percent), but then grew very quickly in the second part of the decade. This likely reflects the occupational upgrading of the FSU immigrants, a phenomenon which has already been

Table 1 Output per worker and total factor productivity in Israel, 1970-1999

\begin{tabular}{|c|c|c|c|c|}
\hline \multicolumn{5}{|c|}{ Average yearly change } \\
\hline & \multicolumn{2}{|c|}{ Output per worker } & \multicolumn{2}{|c|}{ Total factor productivity } \\
\hline & Manufacturing & Total private sector & Manufacturing & Total private sector \\
\hline 1970-1979 & $4.42 \%$ & $4.58 \%$ & $2.22 \%$ & $2.81 \%$ \\
\hline 1980-1989 & $1.67 \%$ & $1.51 \%$ & $0.15 \%$ & $0.91 \%$ \\
\hline 1990-1999 & $3.14 \%$ & $1.04 \%$ & $1.63 \%$ & $0.70 \%$ \\
\hline
\end{tabular}

Source: Author's calculations based on data from the Bank of Israel Annual Report, 2003. 


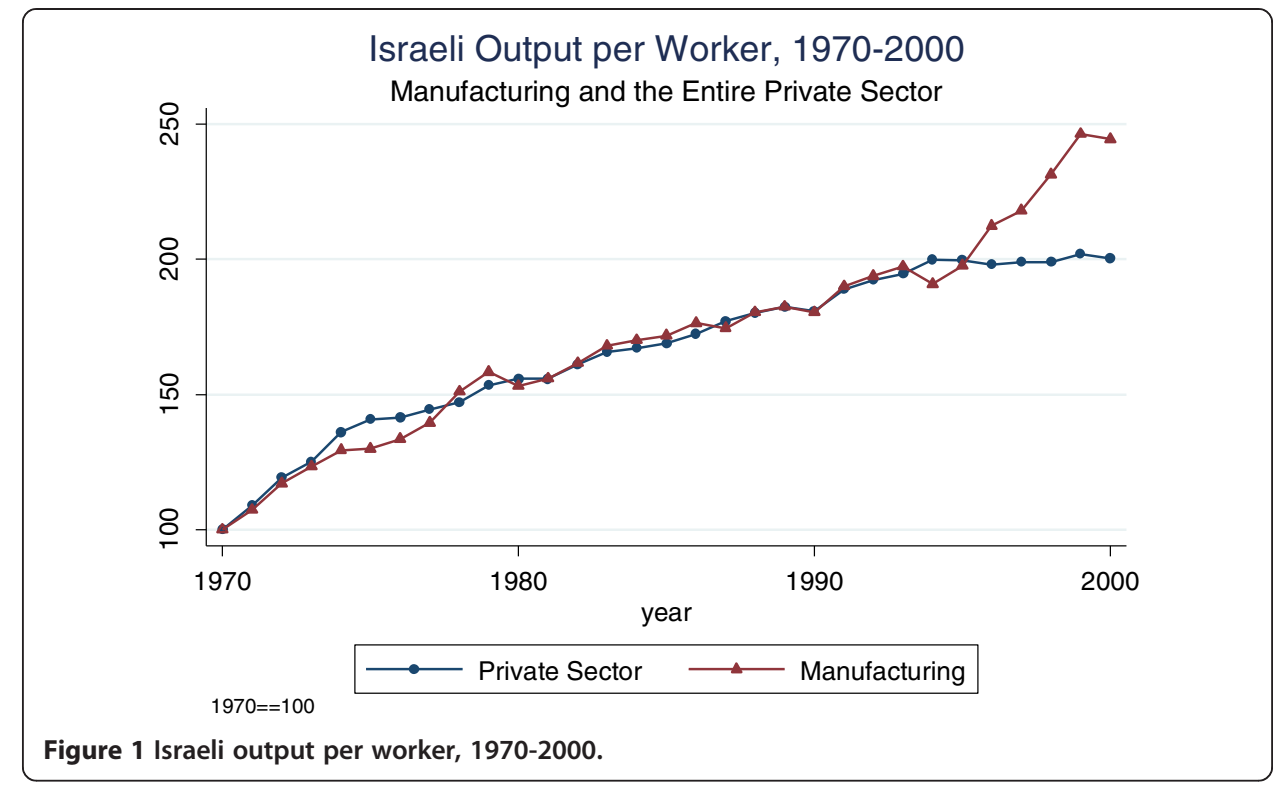

studied extensively in the literature (Weiss, Sauer and Gotlibovsky, 2003; Eckstein and Weiss, 2002 and 2004).

Summing up, it appears that the manufacturing sector as a whole, and in particular high technology industries within this sector, were the main engines of growth in the Israeli economy in the latter part of the 1990s. At the same time, the manufacturing sector absorbed large numbers of highly educated immigrants, who gradually shifted from blue-collar to white-collar occupations. In the next sections we will try to analyze whether these two phenomena are linked at a more disaggregated level.

\section{Data}

The main source of data for my analysis is represented by the 1990-1999 Industrial Surveys conducted annually by the Israeli Central Bureau of Statistics (CBS). The

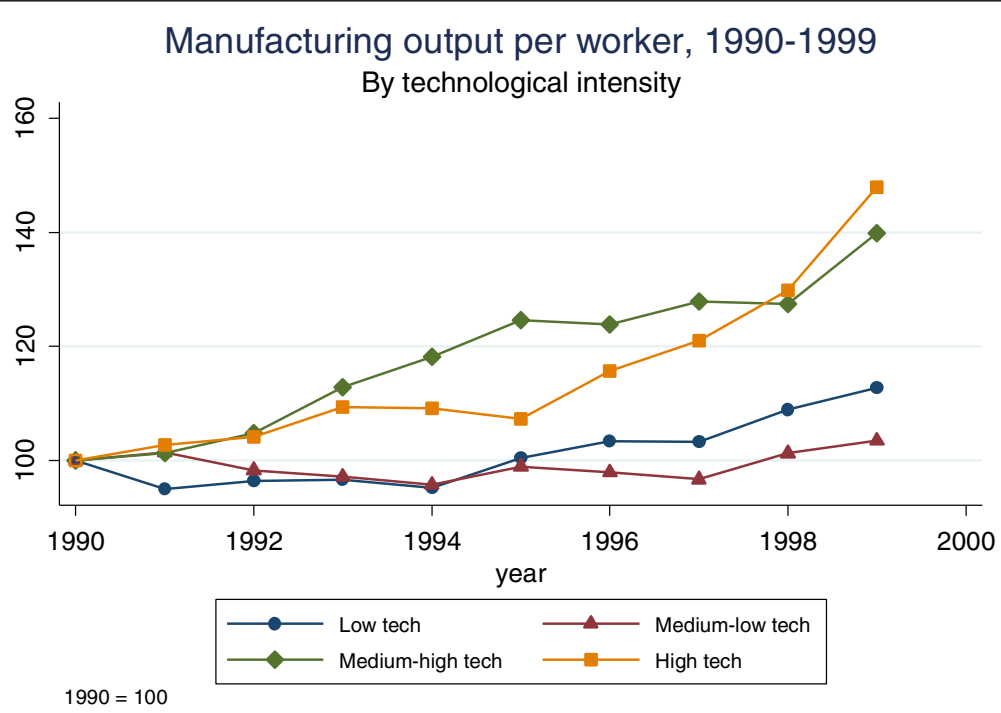

Figure 2 Manufacturing output per worker, by technological intensity. 
Table 2 Employment distribution of immigrants and natives by industry 1991-1999

\begin{tabular}{ccccccc}
\hline & \multicolumn{2}{c}{ Males } & & \multicolumn{2}{c}{ Females } \\
\cline { 2 - 3 } \cline { 5 - 6 } & Immigrants & Natives & & Immigrants & Natives \\
\hline Agriculture & 2.14 & 3.88 & & 1.83 & 1.42 \\
Mining and Manufacturing & 41.68 & 25.15 & & 25.53 & 11.42 \\
Electricity and Water & 1.23 & 1.62 & & 0.27 & 0.36 \\
Construction & 12.39 & 9.93 & & 0.88 & 0.97 \\
Commerce, Restaurants and Hotels & 10.90 & 16.00 & & 15.44 & 12.92 \\
Transport, Storage and Communication & 4.35 & 9.11 & & 1.54 & 3.33 \\
Financing and Business Services & 8.98 & 11.59 & & 10.79 & 13.87 \\
Public and Community Services & 13.12 & 17.84 & & 31.41 & 47.33 \\
Personal and Other Services & 5.22 & 4.88 & & 12.31 & 8.38 \\
Total & 100.00 & 100.00 & & 100.00 & 100.0 \\
Percentage Immigrants & & 9.50 & & & & 11.21 \\
\hline
\end{tabular}

Note: Author's calculations from the 1991-1999 Labor Force Surveys.

survey is a representative sample of manufacturing establishments employing 5 or more persons. Griliches and Regev (1995) used these same surveys to study productivity in Israeli firms during the 1980s.

The Industrial Surveys have been conducted regularly by the CBS since 1955 . The surveys can be viewed as a succession of short panels, since every few years the sampling frame is redesigned and a new sample of establishments is drawn based on probability sampling. Large establishments (with more than 75 employed persons), and a number of smaller establishments in some economic branches are sampled with certainty, while smaller establishments are sampled with a probability determined by establishment size and economic branch. The sampled establishments are then followed for a number of years, until the next sample redesign. In the period under analysis, there were two redesigns of the sample: the 1989 redesign, which is the basis for the 1990-1994 surveys, and the 1994 redesign, which is the basis for the 1995-1999 surveys. Table 3 shows the number of establishments in each survey year, the number

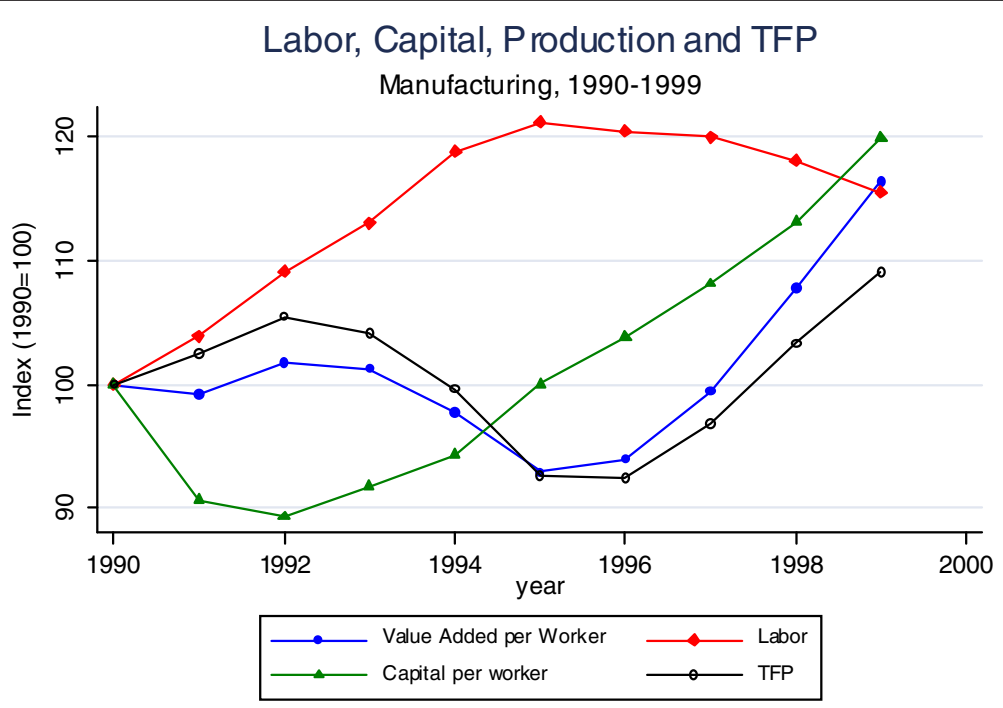

Figure 3 Decomposition of output growth in manufacturing, 1990-1999. 


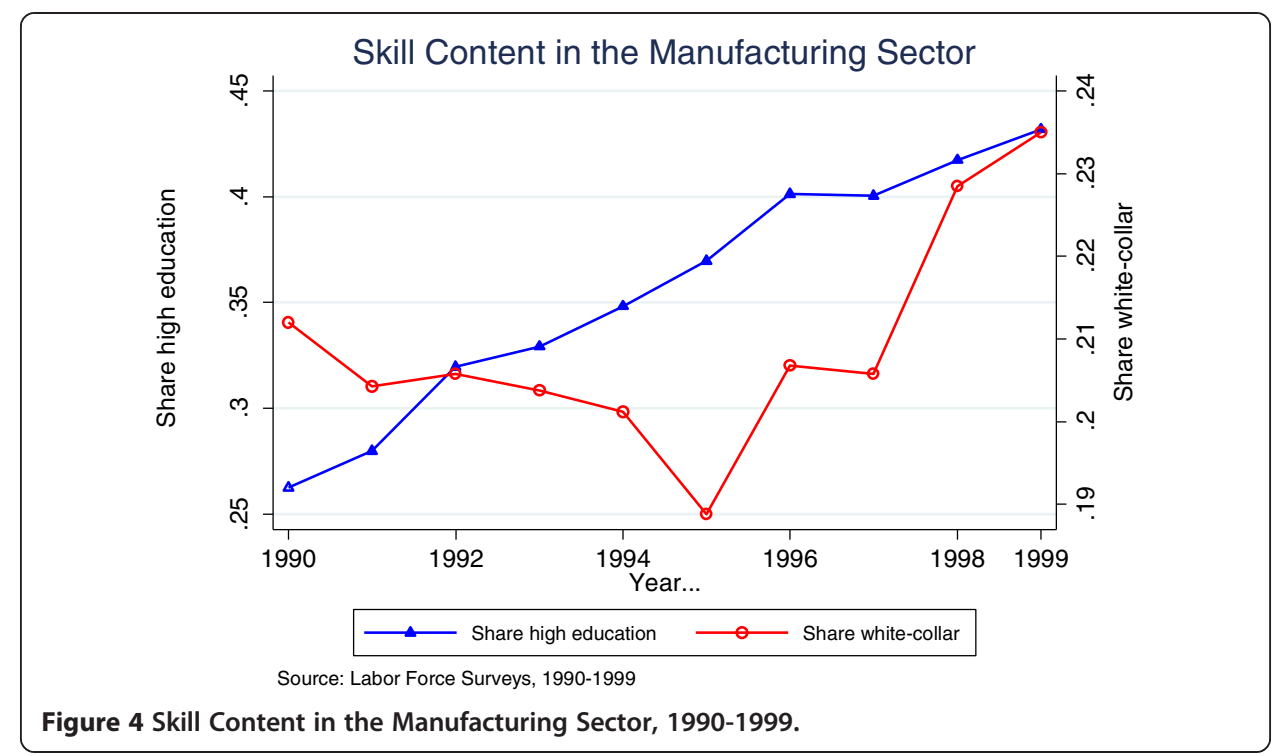

of establishments in each year that were surveyed in 1990, and the number of establishments in each year that were present in 1995. As can be seen, more than 800 establishments in the 1995 sample were already present in 1990, and nearly 700 establishments are sampled continuously between 1990 and $1999^{11}$.

The Industrial Surveys provide information on the usual income and expenditure variables at the firm level: local sales and exports, inventory changes, intermediate inputs, investments broken down by type (buildings, equipment, and vehicles), labor, and wages. These basic data were used to calculate gross output and value added. To calculate each establishment's fixed capital stock, I proceeded as follows: first, I linked each establishment to data on the fixed capital stock at the three-digit industry level from the CBS's 1992 Survey of the Fixed Gross Capital Stock. I then assumed that the capitaloutput ratio is constant within each industry to obtain an estimate of each establishment's stock of equipment, buildings, and vehicles in 1992. Then, I calculated the capital stock

Table 3 Number of establishments in the manufacturing surveys

\begin{tabular}{cccc}
\hline & $\begin{array}{c}\text { Total number of } \\
\text { establishments }\end{array}$ & $\begin{array}{c}\text { Number of establishments } \\
\text { in the sample in 1990 }\end{array}$ & $\begin{array}{c}\text { Number of establishments } \\
\text { in the sample in 1995 }\end{array}$ \\
\hline 1990 & $\mathbf{2 0 8 5}$ & $\mathbf{2 0 8 5}$ & 822 \\
1991 & 2151 & 1936 & 857 \\
1992 & 2158 & 1826 & 878 \\
1993 & 2254 & 1754 & 911 \\
1994 & 2316 & 1666 & 957 \\
1995 & $\mathbf{2 0 4 1}$ & 822 & $\mathbf{2 0 4 1}$ \\
1996 & 1987 & 799 & 1879 \\
1997 & 1950 & 768 & 1761 \\
1998 & 1903 & 739 & 1652 \\
1999 & 1865 & 713 & 1551 \\
Total number of firms in the sample: & 4378 & \\
Firms continuously in the sample, 1990-1999 & 698 & \\
\hline
\end{tabular}

Note: Author's calculations from the 1990-1999 Manufacturing Surveys. Boldface entries represent the number of firms in the first year of each sample redesign. 
for every year using the perpetual inventory method (both forward and backwards, for the years 1990 and 1991), and the linear depreciation formulae used in Regev $(1993)^{12}$.

The CBS follows standard OECD definitions and classifies all industrial sectors into four different levels of technological intensity. I follow this standard classification throughout the paper. Table 4 presents summary statistics on the number of firms, on total employment, and on the composition of the labor force for the four levels of technological intensity. High-technology firms represented 7 percent of the sample in 1990, but employed about 13 percent of the total number of workers in manufacturing. By 1997, the number of high tech firms in the sample had risen to 9 percent, employing now 16 percent of the manufacturing workforce, a 41 percent increase in the level of employment. Note however that employment growth was not confined to the hightech sector alone: employment grew by about 6 percent in the low-tech sector, and by about 47 percent in the medium-low tech sector. Table 4 also shows that the OECD classification reflects fairly accurately the educational composition of the workforce: workers in the high-tech sector have about two and a half more years of schooling than workers in the low tech sector. Moreover, high-tech establishments have a substantial fraction of scientists, and are substantially more likely to invest in R\&D.

\section{The distribution of immigrant employment}

The unique feature of my analysis is the combination of the standard variables on industrial production with information on the type of workforce employed in each establishment. This information is taken from the supplemental surveys on the Structure of the Labor Force (SLF), which were administered to all firms in the Manufacturing Surveys in 1993 and 1997. These surveys collected information on the total number of scientists, white-collar workers ("academics"), technicians, and production workers employed in each establishment, and on the number of recently arrived immigrants in each one of the above categories. This enables me to analyze the characteristics of firms that employed immigrants, and to study whether firms who employed a large number of highly educated immigrants experienced a boost in productivity.

Table 5 presents summary statistics for the SLF data. In the top panel, I present statistics for all the firms with non-missing data in 1993 and 1997, while the bottom panel restricts attention only to those firms that appear in the sample in both 1993 and 1997 (the balanced sample). We must first note the large difference in establishment size between the full sample and the balanced sample. The average number of employees in the full sample is between 29 and 41, but it rises to 130 in the balanced sample. This simply reflects the sampling scheme, whereby large establishments are sampled with certainty, while small establishments only belong to the probability sample. Between 1993 and 1997, the share of firms with at least one immigrant drops from 0.69 to 0.51, while the average number of immigrants per firm increases from 4.21 to 6.20 . This indicates that the employment of immigrants became more concentrated in fewer firms. The average share of immigrants in the firm is fairly stable at 15 to 17 percent of the total workforce.

In contrast to the stability of immigrant employment between 1993 and 1997, there were substantial shifts in the occupational distribution of immigrants within firms, as can be seen from Table 6. The percent of scientists among immigrants more than 
Table 4 Firm characteristics, by technological intensity

\begin{tabular}{|c|c|c|c|c|c|c|c|c|c|c|c|c|}
\hline & \multicolumn{3}{|c|}{ Low-tech } & \multicolumn{3}{|c|}{ Medium-low tech } & \multicolumn{3}{|c|}{ Medium-high tech } & \multicolumn{3}{|c|}{ High-tech } \\
\hline & 1990 & 1993 & 1997 & 1990 & 1993 & 1997 & 1990 & 1993 & 1997 & 1990 & 1993 & 1997 \\
\hline Number of firms & 990 & 1,061 & 832 & 629 & 703 & 655 & 305 & 324 & 284 & 152 & 166 & 179 \\
\hline Total Employment & 129,215 & 145,976 & 137,841 & 74,353 & 91,446 & 109,470 & 51,030 & 48,904 & 49,768 & 40,018 & 46,916 & 56,555 \\
\hline Average years of Schooling & 10.63 & 11.01 & 11.68 & 11.37 & 11.82 & 12.27 & 11.81 & 12.53 & 12.62 & 13.27 & 14.00 & 14.26 \\
\hline Percentage Scientists & - & $0.53 \%$ & $1.27 \%$ & - & $2.43 \%$ & $3.51 \%$ & - & $6.45 \%$ & $8.15 \%$ & - & $23.43 \%$ & $31.99 \%$ \\
\hline Percentage of firms doing $R \& D$ & - & $0.59 \%$ & $0.04 \%$ & - & $0.96 \%$ & $0.54 \%$ & - & $4.46 \%$ & $4.26 \%$ & - & $16.05 \%$ & $21.03 \%$ \\
\hline
\end{tabular}

Note: Author's calculations from the 1990-1999 Manufacturing Surveys, Labor Force Composition Surveys, and Labor Force Surveys. For the classification of industries by technological intensity, see Table 14 in Appendix. 
Table 5 Percentage immigrants in manufacturing: labor force composition surveys, 1993 and 1997

\begin{tabular}{lcc}
\hline & 1993 & 1997 \\
\hline & 2,254 & All firms \\
Number of firms with non-missing LFC data & 28.53 & 1,437 \\
Average number of employees & 0.692 & 40.97 \\
Share of firms hiring immigrants & 4.21 & 0.514 \\
Average number of immigrants in firm & 1 & 6.20 \\
Median number of immigrants in firm & 0.152 & 1 \\
Average share of immigrants in firm & 0.218 & 0.155 \\
Average share of immigrants in firms with at least one immigrants & & 0.301 \\
& 762 & 617 \\
Number of firms with non-missing LFC data & 128.11 & 134.11 \\
Average number of employees & 0.933 & 0.697 \\
Share of firms hiring immigrants & 26.82 & 34.04 \\
Average number of immigrants in firm & 18 & 13 \\
Median number of immigrants in firm & 0.174 & 0.170 \\
Average share of immigrants in firm & 0.186 & 0.244 \\
Average share of immigrants in firms with at least one immigrants
\end{tabular}

Note: Firms in the balanced sample are firms that were present in the sample in 1990, 1993, and 1997.

doubled from 1993 to 1997, going from 4.3 to 9.8 percent. As a result, in 1997 the proportion of immigrants who were scientists was higher than the overall proportion of immigrants in the workforce (15.9 percent versus 15.1 percent). Also, by 1997 a substantial fraction of immigrants were employed in white-collar jobs and as technicians, while the share of immigrants employed as production workers declined from nearly 94 percent to about 81.5 percent. These results further confirm that throughout the 1990s immigrants experienced substantial occupational upgrading, as they acquired local labor market skills and were able to convert part of their imported human capital into something valuable for Israeli employers.

We now move to the question of which industries and firms employed immigrants. Figures 5 and 6 show the immigrant distribution across 25 two-digit manufacturing industries. The dark bars represent high and medium-high tech industries, while the light bars represent low and medium-low tech industries. In 1993 there does not seem to be any evident correlation between the technological intensity of the industry, and

Table 6 Occupational distribution of immigrants in manufacturing

\begin{tabular}{|c|c|c|c|c|c|c|}
\hline & \multicolumn{3}{|c|}{1993} & \multicolumn{3}{|c|}{1997} \\
\hline & \multirow[b]{2}{*}{$\begin{array}{l}\text { Share of occupation } \\
\text { who are immigrants }\end{array}$} & \multicolumn{2}{|c|}{$\begin{array}{l}\text { Occupational } \\
\text { distribution }\end{array}$} & \multirow[b]{2}{*}{$\begin{array}{l}\text { Share of occupation } \\
\text { who are immigrants }\end{array}$} & \multicolumn{2}{|c|}{$\begin{array}{l}\text { Occupational } \\
\text { distribution }\end{array}$} \\
\hline & & Immigrants & Total & & Immigrants & Tota \\
\hline Scientists & 0.074 & 0.043 & 0.075 & 0.159 & 0.098 & 0.093 \\
\hline Academics & 0.021 & 0.004 & 0.026 & 0.081 & 0.022 & 0.042 \\
\hline Technicians & 0.028 & 0.016 & 0.072 & 0.111 & 0.064 & 0.088 \\
\hline $\begin{array}{c}\text { Other } \\
\text { production }\end{array}$ & 0.148 & 0.937 & 0.827 & 0.159 & 0.815 & 0.777 \\
\hline Total & 0.130 & 1.000 & 1.000 & 0.151 & 1.000 & 1.000 \\
\hline
\end{tabular}

Source: Author's calculations from the Structure of Labor Force surveys. 


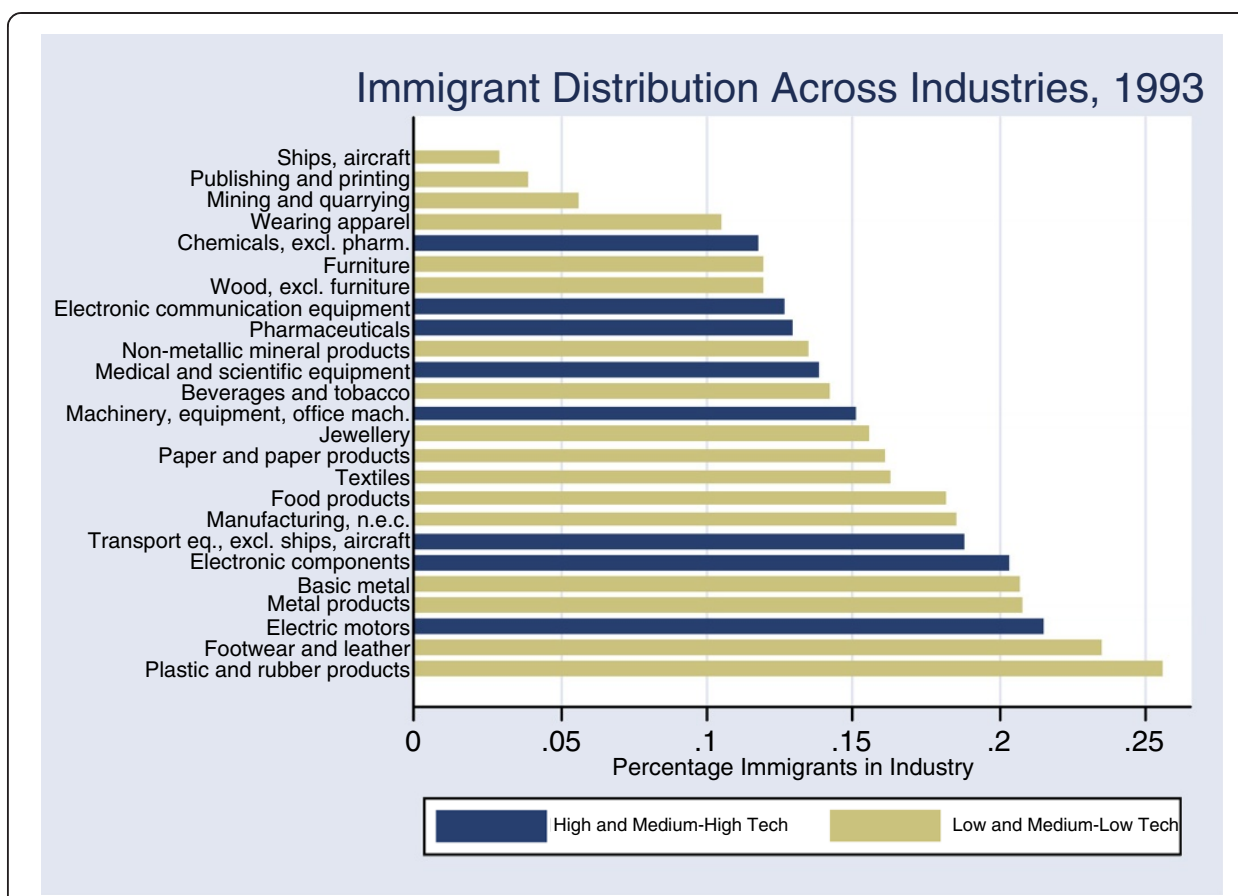

Figure 5 Immigrant Distribution across Industries, 1993.

immigrant concentration. In 1997, the electronic components industry stands out for its high concentration of immigrants, and overall it does seem that there has been a shift of immigrants towards more high-technology sectors.

In Table $7 \mathrm{I}$ investigate directly the determinants of immigrant hiring at the firm level. Specifically, I regress the share of immigrants in the firm, for both 1993 and

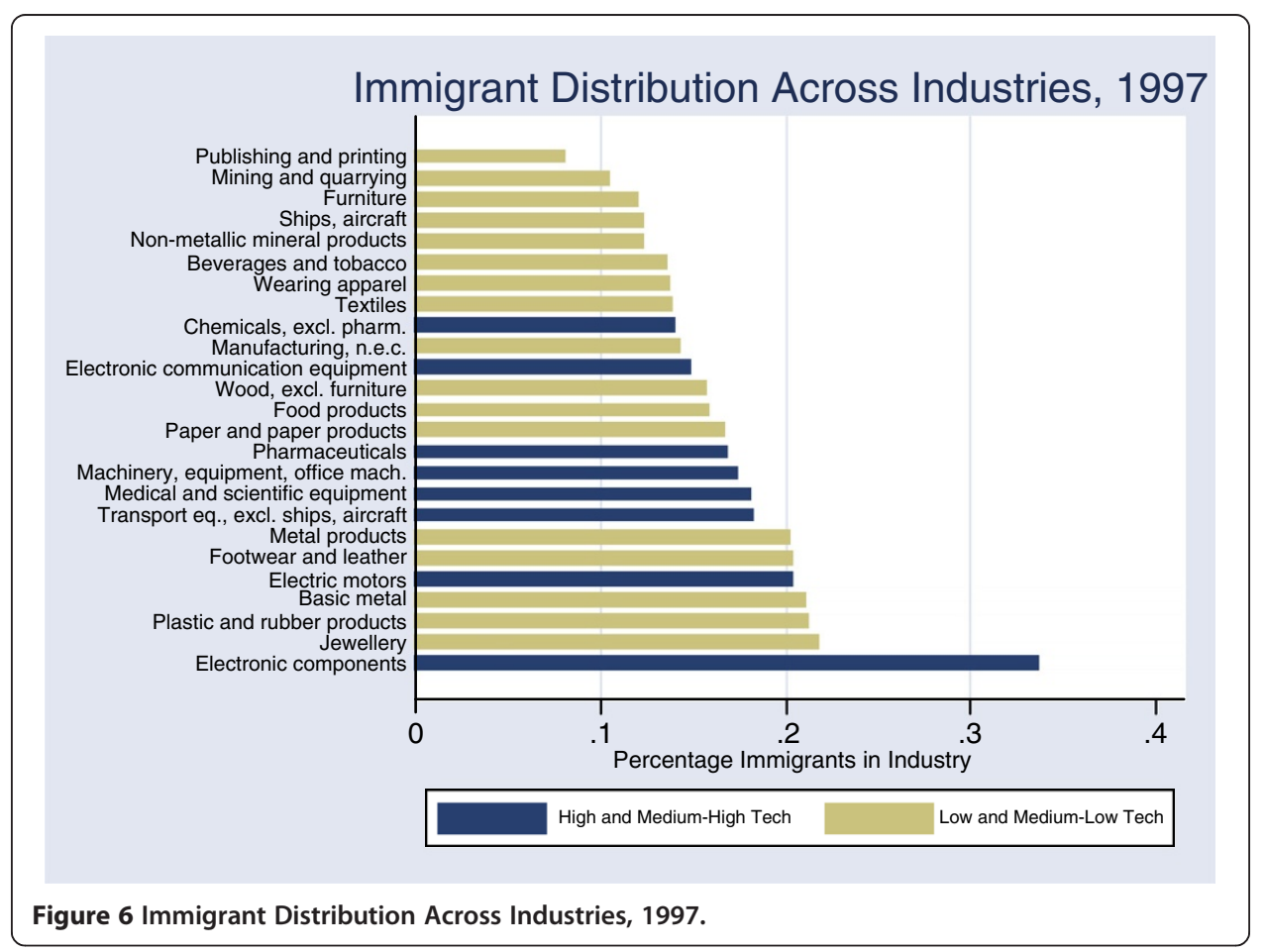


Table 71990 Firm determinants of immigrant concentration, 1993-1997

\begin{tabular}{|c|c|c|c|c|c|c|}
\hline \multirow[b]{3}{*}{ Number employed: 10-24 } & \multirow{2}{*}{\multicolumn{2}{|c|}{$\begin{array}{c}\begin{array}{c}\text { Share immigrants } \\
\text { in } 1993\end{array} \\
\text { All available firms }\end{array}$}} & \multirow{2}{*}{\multicolumn{2}{|c|}{$\begin{array}{c}\begin{array}{c}\text { Share immigrants } \\
\text { in } 1997\end{array} \\
\text { All available firms }\end{array}$}} & \multirow{2}{*}{\multicolumn{2}{|c|}{$\begin{array}{c}\begin{array}{c}\text { Share immigrants } \\
\text { in } 1993\end{array} \\
\text { All firms in } 1997 \text { sample }\end{array}$}} \\
\hline & & & & & & \\
\hline & $0.009(0.014)$ & $0.001(0.013)$ & $0.008(0.053)$ & $-0.006(0.057)$ & $0.051(.044)$ & $0.024(0.044)$ \\
\hline Number employed: 25-49 & $0.039^{* *}(0.152)$ & $0.028^{*}(0.015)$ & $-0.006(0.042)$ & $-0.017(0.055)$ & $0.127^{* *}(0.044)$ & $0.089^{* *}(0.041)$ \\
\hline Number employed: 50-99 & $0.034^{* *}(0.015)$ & $0.022(0.015)$ & $-0.045(0.044)$ & $-0.048(0.050)$ & $0.062(0.042)$ & $0.040(0.041)$ \\
\hline Number employed: 100+ & $0.011(0.015)$ & $-0.002(0.015)$ & $-0.010(0.047)$ & $-0.037(0.049)$ & $0.025(0.040)$ & $-0.006(0.038)$ \\
\hline $\log (K / L)$ & $0.032^{*}(0.009)$ & $0.022^{* *}(0.008)$ & $0.047(0.027)$ & $0.056^{*}(0.029)$ & $0.015(0.013)$ & $0.014(0.013)$ \\
\hline Log Wage & $-0.052^{* *}(0.018)$ & $-0.044^{* *}(0.016)$ & $0.131^{* *}(0.055)$ & $0.086^{* *}(0.042)$ & $-0.053^{*}(0.031)$ & $-0.038(0.030)$ \\
\hline Log value added per worker & $0.014(0.015)$ & $0.019(0.013)$ & $-0.158^{* *}(0.062)$ & $-0.140^{* *}(0.054)$ & $0.019(0.021)$ & $0.015(0.021)$ \\
\hline Output share in 3-digit industry & $-0.131^{* *}(0.065)$ & $-0.129 *(0.066)$ & $-0.246^{* *}(0.149)$ & $-0.161(0.136)$ & $-0.056(0.064)$ & $-0.081(0.066)$ \\
\hline Three-firm concentration index (3-digit industry) & $0.078^{* *}(0.037)$ & $0.081^{* *}(0.039)$ & $-0.020(0.114)$ & $0.061(0.121)$ & $-0.034(0.050)$ & $0.07(0.055)$ \\
\hline Output share $\times$ Concentration index & $-0.216^{* *}(0.096)$ & $-0.206^{* *}(0.101)$ & $0.06(0.218)$ & $0.143(0.221)$ & $-0.088(0.086)$ & $-0.116(0.085)$ \\
\hline Import penetration index (3-digit industry) & $0.099^{* *}(0.038)$ & $0.119^{* *}(0.045)$ & $0.264^{* *}(0.135)$ & $0.364^{* *}(0.132)$ & $0.015(0.057)$ & $0.021(0.059)$ \\
\hline Avg. years of schooling in 3-digit industry & $-0.021^{* *}(0.008)$ & $-0.017(0.011)$ & $0.013(0.022)$ & $0.042(0.030)$ & $-0.014(0.011)$ & $0.001(0.017)$ \\
\hline High tech & $0.047(0.029)$ & - & $0.011(0.087)$ & - & $0.009(0.043)$ & - \\
\hline Medium-high tech & $0.041^{*}(0.022)$ & - & $0.029(0.066)$ & - & $0.020(0.032)$ & - \\
\hline Medium-low tech & $0.061^{* *}(0.014)$ & - & $0.153^{* *}(0.052)$ & - & $0.020(0.027)$ & - \\
\hline Any $R \& D$ & $0.000(0.014)$ & $0.00(0.014)$ & $-0.026(0.031)$ & $-0.024(0.033)$ & $0.004(0.021)$ & $-0.008(0.021)$ \\
\hline Region dummies & Yes & Yes & Yes & Yes & Yes & Yes \\
\hline 2- digit industry dummies & No & Yes & No & Yes & No & Yes \\
\hline $\mathrm{N}$ & 1704 & 1704 & 616 & 616 & 609 & 609 \\
\hline$R^{2}$ & 0.107 & 0.198 & 0.358 & 0.475 & 0.140 & 0.234 \\
\hline
\end{tabular}

Note: Entries in the table represent weighted least squares coefficients, where the weights are the CBS sampling weights. Robust standard errors in parentheses.

*: Statistically different from 0 at the $10 \%$ level. 
1997, on a number of firm characteristics in 1990. This allows me to establish which pre-immigration characteristics of establishments were conducive to the hiring of immigrants. I include in the regressions a number of standard firm characteristics dummies for size, the capital-labor ratio, the 1990 average wage, and value added per worker (all in logs). In addition, I include the concentration level of the industry, the level of competition from imports, and whether the firm enjoys a dominant position within the industry: these variables are meant to capture the fact that maybe workers queue for jobs in firms that enjoy monopoly rents (Katz and Summers, 1989), and outsiders such as immigrants are less likely to find jobs at these firms. Finally, I include a number of indicators for the skill of the workforce and for technological intensity at the industry level: the average years of schooling in the three-digit industry (taken from the Labor Force Survey in 1989-1990), whether the firm engages in R\&D, and dummies for medium-low, medium-high and high-tech industries. I estimate two specifications, with and without two-digit industry fixed effects. The regression is estimated separately for 1993 and 1997.

The results for 1993 suggest that immigrants were more likely to be employed in medium-sized firms rather than in very small or very large firms, but the differences are small and not always statistically significant. More interesting is the coefficient on the capital-labor ratio, which is positive and significant, confirming the intuitive notion that firms that had room to grow (in the sense that they had a high capital-labor ratio) were more likely to hire immigrants. Interestingly, there does not seem to be any correlation between a firm's productivity in 1990 and its propensity to hire immigrants in 1993. There is also some evidence that medium-low tech firms were more likely to hire immigrants, and that immigrant employment is negatively correlated with the average years of schooling in the industry in 1990, although this effect disappears when we control for two-digit industry dummies. The coefficients on the industry concentration variables reveal an interesting pattern: immigrants are more likely to be employed in highly concentrated industries, but not in those firms that enjoy a dominant position within the industry. For example, a firm with a 40 percent output share in an industry with a three-firm concentration index of 0.5 employs on average 5.7 percent $(0.078 \times 0.5$ $0.131 \times 0.4-0.216 \times 0.5 \times 0.4=-0.057)$ fewer immigrants than a (hypothetical) firm in a perfectly competitive industry (i.e., infinitely small output share in an industry where the concentration index is zero). By contrast, a firm in the same industry with only 5 percent market share employs on average 2.7 percent more immigrants than its perfectly competitive counterpart. Similarly, firms that were exposed to greater competition from imports were more likely to employ immigrants. Coupled with the coefficients on the wage variable, these results suggest that there may indeed be queuing for jobs in firms that enjoy monopoly rents and immigrants are the ones least likely to be close to the front of the queue.

The results for 1997 paint a slightly different picture: Now I find a positive correlation between immigrant share and the 1990 wage, and a negative correlation between immigrant concentration and productivity in 1990. It still seems to be the case that immigrants are less likely to be employed in firms that enjoy a dominant position in their market, and they are more likely to be employed in firms that face stiff import competition, but the other variables measuring industry concentration now become insignificant.

It is difficult to tell how much of the differences between 1993 and 1997 depend on actual mobility of immigrants between firms, and how much instead depends on the 
fact that because of the 1995 sample redesign, I can only observe a limited number of establishments (mostly large ones) who were present in both the 1990 and 1997 sample. The last two columns of Table 7 illustrate this problem: I replicate the regressions for the 1993 sample, but now using only those firms that were present in the sample in both 1993 and 1997. Now essentially all the coefficients become insignificant, and it is difficult to draw any strong conclusions about the determinants of immigrant hiring at the firm-level.

Summing up, this section has showed that immigrants were distributed over the entire spectrum of Israeli manufacturing firms. In the early 1990s, immigrants were concentrated in firms with room to grow and with low wages (possibly because access to high paying jobs in firms that enjoy rents is obstructed), but we find little correlation between these firm characteristics and immigrant concentration later in the decade. Two additional findings deserve attention: first, immigrants were not more likely to be employed in high technology firms, which may be viewed as surprising given their high levels of human capital; second, there seems to be little or no correlation between a firm's productivity in 1990 and its propensity to employ immigrants later in the decade. In the next section, where I examine the effect of immigrants on firm productivity, one should keep in mind that there was no apparent pattern of immigrants selectively sorting themselves into firms based on their level of productivity.

\section{The effect of immigrants on productivity}

In this section I estimate a standard production function at the firm level, including the percentage of immigrants as a right hand-side variable. Assume that firms produce output $Y$ using a Cobb-Douglas production function with capital $(K)$, intermediate inputs (or materials, $M$ ), and labor $(L)$ as its inputs. Native labor and immigrant labor (respectively, $L_{N}$ and $L_{I}$ ) are perfectly substitutable in production, but they may have different levels of productivity $^{13}$. Specifically, we write the firm's production function as:

$$
Y=A K^{\alpha} M^{\beta}\left[L_{N}+(1+\mu) L_{I}\right]^{\gamma},
$$

where the parameter $\mu$ denotes the difference in productivity between a unit of immigrant labor relative to a unit of native labor. This difference in productivity may be positive, if for example immigrant workers have on average higher levels of education, or negative, if immigrants face difficulties in adapting to the local work environment, because of language barriers or other forms of low local human capital. I define $s$ as the share of immigrants out of total employment $L$, so that $L_{I}=s L$, and $L_{N}=(1-\mathrm{s}) L$. Then, we can rewrite the production function as:

$$
\begin{aligned}
Y & =A K^{\alpha} M^{\beta} L^{\gamma}[(1-s)+(1+\mu) s]^{\gamma} \\
& =A K^{\alpha} M^{\beta} L^{\gamma}[1+\mu s]^{\gamma},
\end{aligned}
$$

Dividing both sides of the equation by $L$, taking logs, and adding firm and time subscripts yields the estimating equation:

$$
\log \left(\frac{Y}{L}\right)_{i t}=\alpha \ln \left(\frac{K}{L}\right)_{i t}+\beta \ln \left(\frac{M}{L}\right)_{i t}+(\alpha+\beta+\gamma-1) \ln L_{i t}+\gamma \mu s_{i t}+\delta^{\prime} X_{i t}+c_{i}+u_{i t},
$$

where I have used the approximation $\ln (1+\mu s) \approx \mu s$, and I have decomposed the technology shifter $\ln A_{i t}$ into an observed component $\left(\delta^{\prime} X_{i t}\right)$ and a fixed unobserved 
component $\left(c_{i}\right)$. Following Griliches and Regev (1995), the observable technology shifters include the log of R\&D expenditures, a dummy for whether the firm engages in $\mathrm{R} \& \mathrm{D}$ at all, region dummies, and (in some specifications) industry dummies. The $c_{i}$ term is a time-invariant firm specific effect, which is potentially correlated with firm inputs, while $u_{i t}$ is an idiosyncratic error term, uncorrelated with firm inputs. Therefore, the estimating framework reduces to a standard production function, with the proportion of immigrants as an additional right hand side variable.

The coefficients in the above equation can be given a causal interpretation if all the unobserved terms are indeed uncorrelated with the inputs, or if the fixed firm effects can be made to drop out of the equation by either first differencing or by subtracting firm-specific means from both sides of the equation (the within estimator). For the moment, the maintained assumption is that there are no time-varying unobservables at the firm level that are correlated with the fraction of immigrant workers. While this is a fairly strong assumption, it should be remembered that the regressions already control for the standard determinants of productivity and for fairly detailed industry dummies, so that any productivity shocks occurring at the industry level are already accounted for. Later, in the industry-level analysis, I will address the potential endogeneity concern using an instrumental variable strategy ${ }^{14}$.

\section{Basic results}

Table 8 presents the results from cross-sectional and pooled estimation of the production function. These estimates do not include firm fixed effects. Table 9 instead shows results from estimation of the model in first differences, with the firm fixed effect differenced out. All regressions are estimated by weighted least squares, using as weights the CBS provided sampling weights.

The coefficients of the production function in Table 8 are in line with much of the previous literature, and specifically with the findings of Griliches and Regev for the 1972-1988 period. The coefficient on capital in the production function ranges from 0.16 to 0.28 , while the coefficient on intermediate inputs is between 0.42 and 0.52 . The coefficient on employment reveals some evidence for increasing returns to scale, even though one must be cautious with this specification because of the potential endogeneity problem. What is most striking in the table, though, is the fact that the share of immigrants seems to be completely unrelated to productivity. In all specifications, the coefficient on the share of immigrants is small and insignificant, both statistically and economically. For example, the last column (the most comprehensive specification, with both years of data and including industry fixed effects) indicates that an increase in the share of immigrants from 0 to 0.1 is associated with a 0.22 percent increase in labor productivity, and one can rule out effects larger than 0.8 percent. At the bottom of the Table 1 present the implied values of the production function parameters. The implied value of $\mu$ ranges between -0.123 to 0.067 , and is never statistically significant.

In Table 9, I address the possibility that immigrant concentration was correlated with a fixed unobservable component of firm productivity by estimating the firm's production function in first-differenced form. I estimate the relationship separately for 1990-1993 (assuming that the share of immigrants in all firms was zero in 1990) and 
Table 8 Production functions, cross-sectional and pooled estimates full sample dependent variable: log output per worker

\begin{tabular}{|c|c|c|c|c|c|c|}
\hline & 1993 & 1993 & 1997 & 1997 & Pooled, 1993-1997 & Pooled, 1993-1997 \\
\hline Share immigrants & $-0.044(0.054)$ & $0.022(0.055)$ & $-0.034(0.038)$ & $0.008(0.033)$ & $-0.034(0.033)$ & $0.022(0.029)$ \\
\hline Log capital per worker & $0.165^{* *}(0.012)$ & $0.242^{* *}(0.018)$ & $0.201^{* *}(0.019)$ & $0.278^{* *}(0.024)$ & $0.182^{* *}(0.012)$ & $0.245^{* *}(0.015)$ \\
\hline Log materials per worker & $0.517^{* *}(0.015)$ & $0.465^{* *}(0.018)$ & $0.472^{* *}(0.020)$ & $0.424^{* *}(0.020)$ & $0.497^{* *}(0.014)$ & $0.453^{* *}(0.014)$ \\
\hline Log employment & $0.042^{* *}(0.008)$ & $0.041^{* *}(0.007)$ & $0.048^{* *}(0.009)$ & $0.042^{* *}(0.008)$ & $0.044^{* *}(0.006)$ & $0.040^{* *}(0.006)$ \\
\hline Log R\&D expenditures & $0.048^{* *}(0.009)$ & $0.018^{* *}(0.009)$ & $0.026(0.026)$ & $0.019(0.025)$ & $0.039^{* *}(0.011)$ & $0.011(0.010)$ \\
\hline 1 if no $R \& D$ & $-0.183^{* *}(0.028)$ & $-0.096^{* *}(0.028)$ & $-0.176^{* *}(0.052)$ & $-0.059(0.063)$ & $-0.178^{* *}(0.027)$ & $-0.066^{* *}(0.031)$ \\
\hline Region dummies & Yes & Yes & Yes & Yes & Yes & Yes \\
\hline 3-digit industry dummies & No & Yes & No & Yes & No & Yes \\
\hline N & 2087 & 2087 & 1421 & 1421 & 3508 & 3508 \\
\hline$R^{2}$ & 0.863 & 0.895 & 0.850 & 0.890 & 0.855 & 0.887 \\
\hline \multicolumn{7}{|c|}{ Implied production function parameters } \\
\hline$a$ & $0.165^{* *}(0.012)$ & $0.242^{* *}(0.018)$ & $0.201^{* *}(0.019)$ & $0.278^{* *}(0.024)$ & $0.182^{* *}(0.012)$ & $0.245^{* *}(0.015)$ \\
\hline$\beta$ & $0.517^{* *}(0.015)$ & $0.465^{* *}(0.018)$ & $0.472^{* *}(0.020)$ & $0.424^{* *}(0.020)$ & $0.497^{* *}(0.014)$ & $0.453^{* *}(0.014)$ \\
\hline Y & $0.359^{* *}(0.017)$ & $0.334^{* *}(0.016)$ & $0.374^{* *}(0.020)$ & $0.340^{* *}(0.021)$ & $0.365^{* *}(0.013)$ & $0.341^{* *}(0.013)$ \\
\hline$\mu$ & $-0.123(0.150)$ & $0.067(0.164)$ & $-0.092(0.102)$ & $0.023(0.097)$ & $-0.092(0.089)$ & $0.066(0.086)$ \\
\hline
\end{tabular}

Note: Entries in the table represent weighted least squares coefficients, where the weights are the CBS sampling weights. Robust standard errors in parentheses.

*: Statistically different from 0 at the $10 \%$ level.

**: Statistically different from 0 at the $5 \%$ level. 
Table 9 Production functions - first differences estimates dependent variable: change in log output per worker

\begin{tabular}{|c|c|c|c|c|c|c|}
\hline & \multicolumn{3}{|c|}{ Sample: all available firms } & \multicolumn{3}{|c|}{ Sample: balanced sample } \\
\hline & 1990-1993 & 1993-1997 & Pooled & 1990-1993 & 1993-1997 & Pooled \\
\hline Share Immigrants & $-0.048(0.059)$ & $-0.094^{* *}(0.042)$ & $-0.073^{* *}(0.030)$ & $0.065(0.067)$ & $-0.056(0.042)$ & $-0.029(0.036)$ \\
\hline Log capital per worker & $0.188^{* *}(0.044)$ & $0.068(0.044)$ & $0.121^{* *}(0.028)$ & $0.168^{* *}(0.048)$ & $0.049(0.041)$ & $0.071^{* *}(0.034)$ \\
\hline Log materials per worker & $0.584^{* *}(0.031)$ & $0.490^{* *}(0.056)$ & $0.567^{* *}(0.030)$ & $0.651^{* *}(0.044)$ & $0.449 * *(0.055)$ & $0.493^{* *}(0.050)$ \\
\hline Log employment & $0.085^{*}(0.044)$ & $-0.029(0.045)$ & $0.032(0.028)$ & $0.029(0.039)$ & $-0.089^{* *}(0.038)$ & $-0.052(0.035)$ \\
\hline Log R\&D expenditures & $0.006(0.013)$ & $0.001(0.023)$ & $-0.009(0.011)$ & $0.007(0.015)$ & $0.006(0.022)$ & $-0.009(0.012)$ \\
\hline 1 if no $R \& D$ expenditures & $-0.028(0.059)$ & $-0.030(0.152)$ & $-0.088(0.060)$ & $0.012(0.079)$ & $-0.005(0.153)$ & $-0.063(0.073)$ \\
\hline Region dummies & Yes & Yes & Yes & Yes & Yes & Yes \\
\hline 3-digit industry dummies & Yes & Yes & Yes & Yes & Yes & Yes \\
\hline N & 1700 & 661 & 2361 & 611 & 611 & 1222 \\
\hline$R^{2}$ & 0.766 & 0.864 & 0.780 & 0.812 & 0.832 & 0.773 \\
\hline \multicolumn{7}{|c|}{ Implied production function parameters } \\
\hline a & $0.188^{* *}(0.044)$ & $0.068(0.044)$ & $0.121^{* *}(0.028)$ & $0.168^{* *}(0.048)$ & $0.049(0.041)$ & $0.071^{* *}(0.034)$ \\
\hline$\beta$ & $0.584^{* *}(0.031)$ & $0.490^{* *}(0.056)$ & $0.567^{* *}(0.030)$ & $0.651^{* *}(0.044)$ & $0.449 * *(0.055)$ & $0.493^{* *}(0.050)$ \\
\hline Y & $0.312^{* *}(0.027)$ & $0.413^{* *}(0.039)$ & $0.344^{* *}(0.024)$ & $0.210^{* *}(0.045)$ & $0.413^{* *}(0.034)$ & $0.385^{* *}(0.035)$ \\
\hline$\mu$ & $-0.154(0.189)$ & $-0.227^{* *}(0.095)$ & $-0.211^{* *}(0.086)$ & $0.310(0.349)$ & $-0.136(0.100)$ & $-0.076(0.092)$ \\
\hline
\end{tabular}

Note: All the explanatory variables are expressed in first differences. Entries in the table represent weighted least squares coefficients, where the weights are the CBS sampling weights. Robust standard errors

in parentheses.

*: Statistically significant at the $10 \%$ level.

**: Statistically significant at the $5 \%$ level. 
1993-1997, and then pooling both periods together. The first three columns of the table present the results based on the sample of all available firms, while the next three columns restrict attention only to the balanced sample of firms that were surveyed in all three years (1990, 1993 and 1997). I now find some evidence of an adverse effect of the change in immigrant share on productivity growth for the 1993-1997 period and for the pooled specification, but the effect disappears in the balanced sample. In contrast to what seemed to emerge from the time series evidence, at the microeconomic level there is clearly no evidence of a positive effect of immigrant concentration on firm productivity.

\section{Robustness Checks}

I now verify whether the results are robust to using total factor productivity rather than just output per worker as the dependent variable. To calculate total factor productivity at the firm level, I use the factor share approach. For each year, I calculate the share of output accruing to labor, capital and intermediate inputs at the three-digit industry level, and I then calculate total factor productivity at the firm level as $T F P_{i j t}=\ln \left(Y_{i j t}\right)-$ $\alpha_{j t} \ln L_{i j t}-\beta_{j t} \ln K_{i j t}-\gamma{ }_{j t} \ln M_{i j t}$, where $i$ denotes firms, $j$ denotes industries, and $t$ denotes time. I then regress these measures of total factor productivity on the share of immigrants and on the other elements of the production function. The results are presented in Table 10. The first column estimates the regression in levels, while the second and third columns use the first-difference specification for the 1993-1997 period, for the full and balanced samples, respectively. Once again, it appears that, if anything, the share of immigrants has a negative effect on firm productivity.

In Table 11, I perform a series of specification checks of the basic production function estimates. For all specifications, I report the results for the regression in levels, in

Table 10 Immigrants and total factor productivity: the output share approach dependent variable: total factor productivity

\begin{tabular}{cccc}
\hline & $\begin{array}{c}\text { Levels, all available } \\
\text { firms, 1993 and 1997 }\end{array}$ & $\begin{array}{c}\text { First differences, all } \\
\text { available firms, 1990-1993 } \\
\text { and 1993-1997 }\end{array}$ & $\begin{array}{c}\text { First differences, } \\
\text { balanced sample, } \\
\text { 1990-1993 and 1993-1997 }\end{array}$ \\
\hline Share immigrants & $-0.032(0.036)$ & $-0.093^{* *}(0.043)$ & $-0.060(0.064)$ \\
Log capital per worker & $0.140^{* *}(0.015)$ & $0.0249(0.041)$ & $-0.028(0.047)$ \\
Log materials per worker & $-0.099^{* *}(0.014)$ & $0.014(0.030)$ & $-0.051(0.045)$ \\
Log employment & $0.162^{* *}(0.006)$ & $0.152^{* *}(0.041)$ & $0.345(0.043)$ \\
Log R\&D expenditures & $0.062^{* *}(0.019)$ & $-0.018(0.021)$ & $-0.023(0.025)$ \\
1 if no R\&D expenditures & $0.279^{* *}(0.124)$ & $-0.124(0.113)$ & $0.118(0.146)$ \\
Region dummies & Yes & Yes & Yes \\
3-digit industry dummies & Yes & $Y e s$ & Yes \\
$N$ & 3508 & 2361 & 1222 \\
$R^{2}$ & 0.742 & 0.532 & 0.631 \\
\hline
\end{tabular}

Note: The dependent variable is firm-level TFP calculated as $T F P_{i j t}=\ln \left(Y_{i j t}\right)-a_{i t} \ln L_{i j t}-\beta_{j t} \ln K_{i j t}-\gamma_{j t} \ln M_{i j t}$, where $i$ denotes firm, $j$ denotes industry, and $t$ denotes time. These measures are calculated using all the available data from the Industrial Surveys from 1990 to 1999.

*: Statistically significant at the $10 \%$ level.

**: Statistically significant at the $5 \%$ level. 


\section{Table 11 Production functions - nonlinearities and interactions}

\begin{tabular}{|c|c|c|c|}
\hline & Levels, all available firms, 1993 and 1997 & $\begin{array}{c}\text { First differences, all available firms, } \\
1990-1993 \text { and } 1993-1997\end{array}$ & $\begin{array}{c}\text { First differences, balanced sample, } \\
1990-1993 \text { and } 1993-1997\end{array}$ \\
\hline \multicolumn{4}{|l|}{ Nonlinearities in immigrant share } \\
\hline Share immigrants & $0.047(0.079)$ & $0.028(0.085)$ & $-0.036(0.113)$ \\
\hline Share immigrants square & $-0.039(0.097)$ & $-0.132(0.105)$ & $0.010(0.166)$ \\
\hline Industry dummies & 3 digit & 3 digit & 3 digit \\
\hline \multicolumn{4}{|l|}{ Immigrant share and firm size } \\
\hline Share immigrants $\times$ number employed 0-9 & $0.087(0.067)$ & $-0.110^{* *}(0.043)$ & $-0.181(0.124)$ \\
\hline Share immigrants $\times$ number employed 10-49 & $0.011(0.038)$ & $-0.040(0.042)$ & $0.007(0.054)$ \\
\hline Share immigrants $\times$ number employed 50-99 & $0.004(0.049)$ & $-0.050(0.042)$ & $-0.055(0.046)$ \\
\hline Share immigrants $\times$ number employed $100+$ & $-0.220^{* *}(0.065)$ & $-0.056(0.047)$ & $-0.030(0.060)$ \\
\hline Industry dummies & 3 digit & 3 digit & 3 digit \\
\hline \multicolumn{4}{|l|}{ Immigrant share and technological intensity } \\
\hline Share immigrants $\times$ low tech industry & $-0.104^{* *}(0.048)$ & $-0.126^{* *}(0.032)$ & $-0.175^{* *}(0.044)$ \\
\hline Share immigrants $\times$ medium-low tech industry & $-0.015(0.049)$ & $0.065(0.060)$ & $0.022(0.061)$ \\
\hline Share immigrants $\times$ medium-high tech industry & $-0.034(0.058)$ & $0.155^{* *}(0.061)$ & $0.060(0.089)$ \\
\hline Share immigrants $\times$ high tech industry & $-0.044(0.218)$ & $-0.030(0.117)$ & $0.311^{* *}(0.137)$ \\
\hline Industry dummies & None & None & None \\
\hline \multicolumn{4}{|l|}{ Immigrant share and 1989-1990 average years of schooling in industry } \\
\hline Share immigrants $\times$ (average years of schooling $\leq 10.5$ ) & $0.009(0.059)$ & $-0.123^{* *}(0.034)$ & $-0.111(0.077)$ \\
\hline Share immigrants $\times$ (average years of schooling $\in[10.5,11.5$ ) & $-0.014(0.042)$ & $0.045(0.053)$ & $-0.012(0.057)$ \\
\hline Share immigrants $\times$ (average years of schooling $>11.5$ & $-0.018(0.067)$ & $0.063(0.071)$ & $0.065(0.084)$ \\
\hline Industry dummies & 2 digits & 2 digits & 2 digits \\
\hline Number of observations & 3,508 & 2,361 & 1,222 \\
\hline
\end{tabular}

*: Statistically significant at the $10 \%$ level.

**. Statistically significant at the $5 \%$ level. 
first differences for the full sample, and in first differences for the balanced sample in 1993 and 1997. In the top panel of the table, I assess whether the apparent lack of a correlation between the percentage immigrants and productivity is due to nonlinearities in the production function. For example, it could be that immigrants yield productivity gains only if they are in concentrated clusters where there can be knowledge spillovers. This conjecture is soundly rejected: the quadratic term is always small and insignificant, and including it never changes the fact that the linear term is also small and insignificant.

An alternative conjecture is that the effect of immigrants varies by firm size. Again, this could be because knowledge spillovers can occur only in relatively large firms. The different specifications do not present a consistent pattern: in the regression in levels, it appears that the effect of immigrants is most pronouncedly negative in large establishments, while the differences specification suggests that the immigrant share has a negative effect on productivity especially in small firms. Overall, it is unlikely that the explanation for the lack of an effect of immigrant concentration on productivity lies in differences between small and large firms.

The next two panels investigate whether the effect of immigrants on productivity depends on the firm's level of technological intensity, and on the pre-existing level of skills at the industry level ${ }^{15}$. The third panel reveals that the share of immigrants is consistently negatively associated with productivity in low-tech industries, and the coefficient is always statistically significant at the 5 percent level. By contrast, there is some evidence for a positive effect of the immigrants share on productivity in high technology firms, especially in the first-difference specifications. However, the size and significance of the effect are sensitive to whether I use the full or the balanced sample.

The last panel in Table 11 paints a similar picture, although the results are somewhat less precise. There is some evidence that immigrant concentration is negatively correlated with productivity in industries that had a relatively low-skill workforce prior to the migration wave, and is positively correlated with productivity in industries with a high skilled workforce.

I next investigate the hypothesis that perhaps only immigrants who are employed in occupations where their skills can really be put to good use (i.e., scientists) have a positive effect on productivity. I explore this possibility in Table 12. For all three specifications (levels, first differences on the full sample, first differences on the balanced sample), I run a regression that includes the immigrant share among scientists and the immigrant share in all other occupations as right hand side variables. The top panel looks at the relationship in all firms. In all specifications, the correlation between the share of immigrant scientists and productivity is positive but not statistically significant. On the other hand, the coefficient on the share of immigrants in other occupations reflects the results of Tables 8 and 9: small and insignificant in the levels specification, negative and significant in the first difference specification in the full sample, negative and insignificant in the first-difference specification in the balanced sample. The next panels of the table examine whether the effect of immigrant scientists differs by the type of industry. The correlation between the share of immigrants in other occupations and productivity is similar to the one found in Table 11. Interestingly, though, we also find a strong negative correlation between the share of immigrant scientists and productivity in low-tech industries, suggesting that 
Table 12 Production functions - immigrant scientists versus others

\begin{tabular}{|c|c|c|c|c|c|c|}
\hline & \multicolumn{2}{|c|}{ Levels, all available firms, 1993 and 1997} & \multicolumn{2}{|c|}{$\begin{array}{l}\text { First differences, all available firms, } \\
1990-1993 \text { and } 1993-1997\end{array}$} & \multicolumn{2}{|c|}{$\begin{array}{l}\text { First differences, balanced sample, } \\
1990-1993 \text { and } 1993-1997\end{array}$} \\
\hline & $\begin{array}{l}\text { Share immigrant } \\
\text { scientists }\end{array}$ & $\begin{array}{l}\text { Share immigrants } \\
\text { other occ. }\end{array}$ & $\begin{array}{l}\text { Share immigrant } \\
\text { scientists }\end{array}$ & $\begin{array}{l}\text { Share immigrants } \\
\text { other occ. }\end{array}$ & $\begin{array}{l}\text { Share immigrant } \\
\text { scientists }\end{array}$ & $\begin{array}{l}\text { Share immigrants } \\
\text { other occ. }\end{array}$ \\
\hline All firms & $0.386(0.438)$ & $0.013(0.030)$ & $0.014(0.198)$ & $-0.073^{* *}(0.028)$ & $0.221(0.229)$ & $-0.034(0.040)$ \\
\hline Industry dummies & \multicolumn{2}{|c|}{3 digit } & \multicolumn{2}{|c|}{3 digit } & \multicolumn{2}{|c|}{3 digit } \\
\hline Low tech industries & $1.005(0.664)$ & $-0.108(0.049)$ & $-0.977^{* *}(0.225)$ & $-0.119^{* *}(0.032)$ & $-0.734^{* *}(0.258)$ & $-0.154^{* *}(0.050)$ \\
\hline Medium-low tech industries & $-0.290(0.279)$ & $-0.009(0.050)$ & $0.185(0.131)$ & $0.058(0.063)$ & $0.254(0.294)$ & $0.019(0.069)$ \\
\hline Medium-high tech industries & $0.092(0.212)$ & $-0.046(0.059)$ & $0.677(0.467)$ & $0.131^{* *}(0.057)$ & $0.220(0.628)$ & $0.056(0.094)$ \\
\hline High tech industries & $1.250(0.882)$ & $-0.267(0.174)$ & $-0.219(0.460)$ & $0.045(0.118)$ & $0.541(0.402)$ & $0.271 *(0.148)$ \\
\hline Industry dummies & \multicolumn{2}{|c|}{ None } & \multicolumn{2}{|c|}{ None } & \multicolumn{2}{|c|}{ None } \\
\hline Average years of schooling $\leq 10.5$ & $-0.352(0.512)$ & $0.014(0.059)$ & $0.241(0.181)$ & $-0.125^{* *}(0.034)$ & $0.707(0.819)$ & $-0.124(0.077)$ \\
\hline Average years of schooling $\in[10.5,11.5)$ & $-0.046(0.386)$ & $-0.014(0.044)$ & $0.137(0.263)$ & $0.043(0.057)$ & $0.241(0.364)$ & $-0.013(0.066)$ \\
\hline Average years of schooling $>11.5$ & $0.708(0.600)$ & $-0.079(0.074)$ & $-0.215(0.390)$ & $0.086(0.065)$ & $-0.150(0.332)$ & $0.056(0.087)$ \\
\hline Industry dummies & \multicolumn{2}{|c|}{2 digits } & \multicolumn{2}{|c|}{2 digits } & \multicolumn{2}{|c|}{2 digits } \\
\hline
\end{tabular}

**: Statistically significant at the $5 \%$ level. 
mismatched workers may be harmful for productivity. The effect of immigrant scientists in other technology categories is never statistically significant. Finally, splitting industries based on the level of education in 1989-1990 yields mostly insignificant coefficients. Altogether, there does not seem to be too much evidence that immigrants employed as scientists had any positive effects on productivity, either overall or in specific industries.

\section{Industry-level regressions}

Finally, I investigate the hypothesis that a firm's productivity is affected not only by its own characteristics, but also by its surroundings. For example, productive ideas from FSU immigrants might spillover to competing firms, or perhaps induce competitors (with fewer FSU immigrants) to develop independently productive ideas. If this is the case, there could be an aggregate positive effect of immigration on productivity without one that showed up differentially across plants.

To assess this conjecture, I re-estimate the production functions with data aggregated up to the three-digit industry level. If spillovers occur at the three-digit industry level (but there are no spillovers across industries), we would expect to find a positive effect of the immigrant share on productivity, even if there is no correlation between immigrant share and productivity within industries. One of the advantages of using the aggregated data is that I can use the Labor Force surveys to calculate a yearly series of the immigrant share at the industry level. This enables me to exploit the data from 1990 to 1999 in its entirety.

Table 13 Production functions, three-digit industries

\begin{tabular}{|c|c|c|c|c|c|}
\hline \multirow[b]{3}{*}{ Share immigrants } & \multicolumn{5}{|c|}{ Dependent variable: log output per worker } \\
\hline & \multirow{2}{*}{$\begin{array}{c}\text { Pooled OLS } \\
-0.284^{* *}(0.086)\end{array}$} & \multirow{2}{*}{$\begin{array}{l}\text { Fixed Effects } \\
-0.028(.040)\end{array}$} & \multicolumn{3}{|c|}{$\begin{array}{l}\text { Fixed Effects, IV (Instrument: } \\
\text { predicted immigrant share) }\end{array}$} \\
\hline & & & $0.216(.554)$ & $0.052(.173)$ & $-0.004(.308)$ \\
\hline Log capital per worker & $0.100^{* *}(.021)$ & $0.007(.013)$ & $0.001(.015)$ & $0.005(0.014)$ & $0.006(.013)$ \\
\hline $\begin{array}{l}\text { Log materials } \\
\text { per worker }\end{array}$ & $0.782^{* *}(.022)$ & $0.797^{* *}(.025)$ & $0.806^{* *}(.030)$ & $0.801^{* *}(.024)$ & $0.797^{* *}(.026)$ \\
\hline Log employment & $0.021(.014)$ & $-0.035^{* *}(.015)$ & $-0.037^{* *}(.017)$ & $-0.041^{* *}(.018)$ & $-0.045^{* *}(.018)$ \\
\hline Time controls & Year dummies & Year dummies & Year dummies & Two time periods & Linear time trend \\
\hline N & 760 & 760 & 760 & 760 & 760 \\
\hline$R^{2}$ & 0.960 & 0.938 & 0.875 & 0.882 & 0.882 \\
\hline First stage F- statistic & - & - & 5.014 & 17.05 & 10.79 \\
\hline \multicolumn{6}{|c|}{ Implied production function parameters } \\
\hline a & $0.100^{* *}(.021)$ & $0.007(.013)$ & $0.001(.015)$ & $0.005(0.014)$ & $0.006(.013)$ \\
\hline$\beta$ & $0.782^{* *}(.022)$ & $0.797^{* *}(.025)$ & $0.806^{* *}(.030)$ & $0.801^{* *}(.024)$ & $0.797^{* *}(.026)$ \\
\hline Y & $0.139 * *(.019)$ & $0.162^{* *}(.021)$ & $0.156^{* *}(.026)$ & $0.153^{* *}(.021)$ & $0.153^{* *}(.026)$ \\
\hline$\mu$ & $-2.047^{* *}(.695)$ & $-0.173(.246)$ & $1.390(3.680)$ & $0.339(1.144)$ & $-0.025(2.012)$ \\
\hline
\end{tabular}

Notes: Entries in the table represent the coefficients in a production function regression estimated at the three-digit industry level. The share of immigrants at the three-digit industry level is taken from the Labor Force Surveys. See text for the description of the instrument. Robust standard errors robust, adjusted for clustering at the industry level, in parentheses. *: Statistically significant at the $10 \%$ level.

**: Statistically significant at the $5 \%$ level. 
The estimates of the production function at the three-digit industry level are presented in the first two columns of Table 13. The pooled OLS specification reveals a very large negative coefficient on the share of immigrants (perhaps implausibly so), but the coefficient probably reflects mostly the sorting of immigrants across industries (see also Table 7). The coefficients in the fixed effects specification are quite similar to those obtained in using the firm-level data.

An additional advantage of using the aggregated data is that it becomes possible to address the potential endogeneity of the immigrant share using an instrumental variable strategy. The instrument is an adaptation of the Card (2001) shift-share instrument. Specifically, I calculate for every three-digit industry the predicted number of immigrants assuming that the post-1989 distribution of immigrants across industries was the same as the one in 1983. The distribution of immigrants across industries in 1983 is calculated using the Israeli Census, and immigrants are defined to be those individuals who migrated to Israel after 1971. The rationale for this instrument is that it isolates only the part of the variation in the immigrant share due to the tendency of immigrants to be employed in sectors where previous cohorts of immigrants were employed (perhaps because newer cohorts of immigrants are referred to jobs by less recent immigrants in the industries in which they are employed). Thus, the instrument should be uncorrelated with any productivity shocks at the industry level that occurred after 1989.

The IV results (with industry fixed effects) are presented in the last three columns of Table 13. It turns out that the estimates are somewhat sensitive to the exact specification of the time controls. In the base specification (with a full set of year dummies, column 3), the first stage F-statistic is quite small, indicating that there is likely to be a weak-instrument problem. The coefficient on the immigrant share is large and positive, but estimated quite imprecisely. Imposing more structure on the pattern of time effects (columns 4 and 5) alleviates the weak instruments problem (the first stage F-statistics are now above 10 in both specifications), and the coefficient on the share of immigrants becomes small and insignificant. The returns to scale parameters are not very sensitive to specification of the time effects, whereas the parameter $\mu$ is, but it is estimated too imprecisely to draw strong conclusions.

Overall, the findings of the industry-level analysis are in accordance with those obtained using the firm-level data: there is little evidence that immigrants had any effect on productivity, nor is there evidence of knowledge spillovers at the industry level.

\section{Conclusion}

This paper has studied whether the high-skilled migration wave from the former Soviet Union to Israel had any effects on the productivity of Israeli manufacturing firms. The paper uses a unique micro-level data set, in which standard measures of productivity are augmented with information on the composition of the workforce, and, specifically, the share of immigrants at the firm level. Even though the macroeconomic is suggestive of a causal link between immigration and productivity, the detailed micro-level analysis reveals no evidence of a positive correlation between a higher concentration of immigrants and firm productivity. If anything, there is 
robust evidence that immigrant concentration was negatively related to productivity in low-technology industries. There is some evidence of a positive effect of immigrants on productivity in high technology industries, but the magnitude and significance of the results are sensitive to the econometric specification. An industry-level analysis provides no support for the hypothesis of knowledge spillovers at the industry level.

It is worthwhile to try to reconcile these results with those in the existing literature. Quispe-Agnoli and Zavodny (2002), using data from the U.S. manufacturing sector and an econometric approach that is similar to mine, similarly find no evidence of a positive relationship between the immigrant share and labor productivity. They conclude that "slower productivity growth may be the result of the gradual process of assimilation for many immigrants; the negative effect on productivity growth may disappear as immigrants acquire language skills and familiarity with U.S. labor market institutions." (Quispe-Agnoli and Zavodny, 2002, p. 10). On the other hand, Peri (2011), using a longer time period and data aggregated at the state level, and not limited to the manufacturing sector, reaches the opposite conclusion. He conjectures that part of the productivity effect may be attributable to efficient specialization of immigrants and natives in different types of tasks. My results are in fact consistent with both studies: at the macroeconomic level, I also find that total factor productivity increased in the medium-run (as in Peri), even though there is no evidence of increased labor productivity at the firm or the industry level (as in Quispe-Agnoli and Zavodny). One can reconcile these findings using a version of Peri's efficient specialization hypothesis, in which immigrants and natives sort themselves efficiently across industries to increase aggregate productivity. This conclusion, however, should be viewed with some caution, given the absence of a direct link between immigration and productivity.

What lessons then can be learned about the effects of high-skill immigration on productivity for other countries that plan to move towards a more skill-biased immigration policy? This paper raises some doubts as to whether Israel succeeded in exploiting the extraordinary windfall in human capital represented by the Soviet immigration to its full extent. Of course, the Israeli experience has some distinctive features that set it apart from other countries. The sheer magnitude of the migration wave made it more difficult for immigrants to find suitable jobs, and many immigrants fled the disintegrating Soviet Union in haste, and with little prior knowledge of their chances to integrate successfully in the host country. However, other features of this migration wave are likely to be shared by other immigrant-receiving countries. Language and cultural barriers may prevent immigrants, potentially even the highly skilled ones, from rapidly assimilating and contributing to the economy in proportion to their potential.

\section{Endnotes}

${ }^{1}$ See Friedberg and Hunt (1995) for a survey of the early literature, or Card (2005), for a more recent appraisal. On the other hand, Borjas (2003) argues that immigration does have an adverse effect on the employment and wages of natives with the same education and experience as that of immigrants, but there is some debate about the 
effect of immigration as a whole on the average wages of native workers (Borjas, 2003; Ottaviano and Peri 2012). Studies of the Israeli experience in the 1990s have also found contrasting results: Friedberg (2001) finds that the effect of immigration on native wages and employment is sensitive to the estimation procedure, while Cohen-Goldner and Paserman (2011) find some adverse effect on wages in the short run, but no effect in the long run.

${ }^{2}$ For example, in the US output per hour in manufacturing grew at an average annual rate of 4.7 percent from 1990 to 2000, a substantial increase from the 2.8 percent increase during the 1980s (Source: http://www.bls.gov/news.release/prod4. nro.htm).

${ }^{3}$ Other papers that have looked at how the educational composition of the workforce affects productivity are Hellerstein, Neumark and Troske (1999) and Jones (2001).

${ }^{4}$ The data are from the Bank of Israel Annual Report (2003).

5 See the Appendix for the full classification of industries by technological intensity.

${ }^{6}$ About $85 \%$ of post-1989 immigrants arrived from the Former Soviet Union. The current discussion does not distinguish immigrants by country of origin, as this information is also not available in the firm-level data used in the main analysis.

${ }^{7}$ The LFS is the main source for labor force statistics in Israel, and it is the equivalent of the Current Population Survey in the United States.

${ }^{8}$ Weiss, Sauer and Gotlibovski (2003) report that more than $70 \%$ of the immigrants worked in high-skill or medium-skill occupations in the USSR, and the supply of engineers and physicians roughly doubled between 1989 and 1993.

${ }^{9}$ Capital per worker in the manufacturing sector was derived directly from the micro data. See below (Section 4) for details of the calculations.

${ }^{10}$ The dynamic adjustment of the capital stock is key for understanding the evolution of wages over time in response to a migration shock (see Ottaviano and Peri, 2012; and Cohen-Goldner and Paserman, 2011, who present empirical evidence of this adjustment in the Israeli context).

${ }^{11}$ For more detailed descriptions of the sampling procedures, see Israel Central Bureau of Statistics (various years).

${ }^{12}$ Specifically, I assumed that buildings depreciate fully after 35 years, equipment after 15 years, and vehicles after 8 years.

${ }^{13}$ See Hellerstein, Neumark and Troske (1999) and Hellerstein and Neumark (1999) for a more elaborate version of this approach.

${ }^{14}$ I have also tried to use the Olley and Pakes semiparametric estimator (Olley and Pakes, 1996), which explicitly accounts for the potential endogeneity of input demands, even after controlling for firm fixed effects. The resulting estimates are qualitatively and quantitatively similar to the ones reported here.

15 The specification in the third panel does not include industry dummies, since technological intensity essentially varies only at the 2-digit industry level (there is within variation in the measure of technological intensity only in two 2-digit industries: 24 - manufacture of chemicals and chemical products; and 35 - manufacture of transport equipment). The specification in the fourth panel includes only 2-digit industry dummies, since the average level of schooling varies at the 3-digit industry level. 


\section{Appendix}

See below Table 14 for the full classification of industries by technological intensity.

\section{Table 14 Manufacturing industries, by technological intensity}

140 Processing of meat and poultry

141 Processing of fruit and vegetables

142 Processing of fish

143 Manufacture of edible oils, margarine

and oil products

144 Manufacture of dairy products

and ice cream

145 Manufacture of grain mill products

146 Bakeries

147 Manufacture of cakes, cookies and biscuits

148 Manufacture of unleavened bread

149 Manufacture of noodles and pastry

150 Manufacture of sugar

151 Manufacture of chocolate, cocoa

and sugar confectionery

152 Manufacture of prepared food
Medium-low tech

Medium-high tech

230 Manufacture of refined petroleum

and its products

231 Processing of nuclear fuel

131 Mining of minerals and extraction of salts

138 Mining and quarrying of non-metallic minerals n.e.c.

250 Manufacture of plastic boards and pipes

251 Manufacture of plastic sleeves and sheets

252 Manufacture of plastic containers and bottles

253 Manufacture of products from armored

plastic

254 Manufacture of plastic products for kitchen table and domestic uses

255 Manufacture of plastic products for technical, agricultural and industrial uses

241 Manufacture of fertilizers plastics in primary forms
High-tech

245 Manufacture of pharmaceutical products for human veterinary use

300 Manufacture of office machinery

240 Manufacture of basic industrial chemicals

prot Manufacture of automatic data processing machinery

320 Manufacture of electronic components

242 Manufacture of petrochemicals and

243 Manufacture of pesticides and disinfectants

321 Manufacture of semi-conductors

244 Manufacture of paints and varnishes

330 Manufacture of telecommunication equipment

331 Manufacture of data-communication equipment

246 Manufacture of soap, detergents and cosmetics 332 Manufacture of domestic electronic equipment

247 Manufacture of man-made fibers

340 Manufacture of industrial equipment for control and supervision

248 Manufacture of chemical products n.e.c.

341 Manufacture of medical and surgical equipment

290 Manufacture of general purpose machinery 342 Manufacture of instruments for and equipment, parts and maintenance thereof

291 Manufacture of agricultural and forestry machinery parts and maintenance thereof

measuring, testing, and navigating

292 Manufacture of industrial machinery, 343 Manufacture of optical instruments and photographic equipment

355 Manufacture of aircraft 
160 Manufacture of wine and other alcoholic beverages 256 Manufacture of plastic products n.e.c.

161 Manufacture of beer and malt

257 Manufacture of rubber products

162 Manufacture of soft drinks

163 Manufacture of tobacco products

170 Spinning, winding and interweaving of yarns

171 Weaving of fabrics

172 Weaving of terry towels

173 Finishing of textiles

174 Manufacture of bedclothes and bedspreads

175 Manufacturing of other textile products

176 Manufacture of carpets and rugs

177 Manufacture of knitted fabrics

178 Manufacture of knitted wearing apparel

180 Manufacture of outwear (except knitted) and tailors dressmakers

181 Manufacture of swim suits

182 Manufacture of underwear (excl. knitted)

188 Manufacture of wearing apparel n.e.c

190 Tanneries
258 Manufacture of tyres and tubes

260 Manufacture of glass and glass products

261 Manufacture of ceramic tiles

262 Manufacture of other ceramic products

263 Manufacture of cement and plaster

264 Manufacture of articles of cement concrete,plaster and clay

265 Cutting, shaping and finishing of stone

268 Manufacture of non-metallic

mineral products n.e.c

270 Manufacture of basic iron and steel

271 Manufacture of non-ferrous and

precious metals

272 Iron and steel founders

273 Founders of non-ferrous metals

274 Manufacture of metal pipes

products, tanks and steam boilers
294 Manufacture of domestic appliances

310 Manufacture of electric motors, generators and transformers

311 Manufacture of electricity distribution and control apparatus

312 Manufacture of insulated wire and cables

313 Manufacture of cells and batteries

350 Manufacture of motor vehicles

351 Manufacture of bodies for motor vehicles, trailers and semi-trailers

352 Manufacture of parts for motor vehicles

354 Manufacture of railway equipment

358 Manufacture of transport equipment n.e.c. 
191 Manufacture of footwear and footwear

articles of leather and its substitutes

192 Manufacture of products of leather

and leather substitutes n.e.c.

200 Sawmills

201 Manufacture of plywood and by-products

281 Metal processing (metal workshops)

202 Manufacture of builders' carpentry and

joinery and of wood products n.e.c.

210 Basic manufacture of paper and cardboard

211 Manufacture of paper and cardboard products

220 Publishing of books, pamphlets and

other publications

222 Printing and service activities related to printing

223 Publishing and reproduction of recorded media

360 Manufacture of furniture (excl. metal

and plastic one)

361 Manufacture of metal furniture

362 Manufacture of plastic furniture

282 Metal coating

283 Manufacture of cutlery

284 Manufacture of cutting and hand tools

285 Manufacture of plumbing fixtures

286 Manufacture of tinware products

287 Manufacture of wire and wire products

288 Manufacture of metal products

n.e.c. and n.s.

353 Building of ships and boats

380 Manufacture of goldsmiths' articles

381 Manufacture of silversmiths' articles

382 Manufacture of gift items

390 Manufacture of musical instruments

391 Manufacture of sports goods

392 Manufacture of toys and games

393 Manufacture of medical equipment and

orthopedic articles

394 Manufacture of disposable medical equipment

395 Manufacture of school and office supplies

398 Manufacture of products n.e.c. 


\section{Competing interests}

The IZA Journal of Migration is committed to the IZA Guiding Principles of Research Integrity. The author declares that he has observed these principles.

\section{Acknowledgements}

I wish to thank Haim Regev, Saul Lach, Jordi Jaumandreu, Marc Rysman and participants in seminars at the STE program of the Neaman Institute, at the LABORatorio Riccardo Revelli in Moncalieri, and at IZA in Bonn. Libe Crenzel, Anat Katz and Edi Mishitz of the Israeli Central Bureau of Statistics provided helpful assistance with the data. I am grateful to the Samuel Neaman Institute for generous financial support. E-mail: paserman@bu.edu.

The Responsible Editor is: Denis Fougere

\section{Author details}

'Boston University, Boston, USA. ${ }^{2}$ NBER, Cambridge, USA. ${ }^{3}$ CEPR, London, UK. ${ }^{4}$ IZA, Bonn, Germany. ${ }^{5}$ CREAM, London, UK.

\section{Received: 7 March 2013 Accepted: 26 March 2013}

Published: 29 April 2013

\section{References}

Bank of Israel (2003) Bank of Israel Annual Report. , Jerusalem, Israel

Bleakley H, Chin A (2004) "Language Skills and Earnings: Evidence from Childhood Immigrants.". Review of Economics and Statistics 86(2):481-96

Borjas GJ (2003) The Labor Demand Curve is Downward Sloping: Reexamining the Impact of Immigration on the Labor Market. Quarterly Journal of Economics 118, No. 4:1335-1374

Card D (January 2001) Immigrant Inflows, Native Outflows, and the Local Labor Market Impacts of Higher Immigration. Journal of Labor Economics 19(1):22-64

Card D (November 2005) Is the New Immigration Really So Bad? Economic Journal 115(507):F300-323

Chaloff J, Lemaître G (2009) Managing Highly-Skilled Labour Migration: A Comparative Analysis of Migration Policies and Challenges in OECD Countries," OECD Social, Employment and Migration Working Papers, No. 79. OECD Publishing, http://dx.doi.org/10.1787/225505346577

Cohen-Goldner S, Daniele PM (2011) The Dynamic Impact of Immigration on Natives' Labor Market Outcomes: Evidence from Israel. European Economic Review 55(8):1027-45

Cohen-Goldner S, Eckstein Z (2010) Estimating the Return to Training and Occupational Experience: The Case of Female Immigrants. Journal of Econometrics 156(1):86-105

Eckstein Z, Weiss Y (2002) 'The Integration of Immigrants from the Former Soviet Union in the Israeli Labor Market. In: Ben-Bassat A (ed) The Israeli Economy, 1985-1998: From Government Intervention to Market Economics, Essays in Memory of Prof. Michael Bruno. MIT Press, Cambridge

Eckstein Z, Weiss Y (2004) On the Wage Growth of Immigrants: Israel 1990-2000. Journal of the European Economic Association 2(4):665-695

Friedberg RM (2000) "You Can't Take It with You? Immigrant Assimilation and the Portability of Human Capital". Journal of Labor Economics 18(2):221-51

Friedberg RM (2001) The Impact of Mass Migration on the Israeli Labor Market. Quarterly Journal of Economics 116(4):1373-1408

Friedberg RM, Hunt J (Spring 1995) The Impact of Immigrants on Host Country Wages, Employment and Growth. Journal of Economic Perspectives 9(2):23-44

Gandal Neil H, Gordon H, Slaughter Matthew J (2004) Technology, Trade and Adjustment to Immigration in Israel. European Economic Review 48(2):403-428

Griliches Z, Regev H (1995) Firm Productivity in Israeli Industry: 1979-1988. Journal of Econometrics 65(1):175-203

Hellerstein Judith K, Neumark D (1999) Sex, Wages, and Productivity: An Empirical Analysis of Israeli Firm-Level Data. International Economic Review 40(1):95-123

Hellerstein Judith K, Neumark D, Troske Kenneth R (1999) Wages Productivity and Worker Characteristics: Evidence from Plant-Level Production Functions and Wage Equations. Journal of Labor Economics 17(3):409-446

Hercowitz Z (2002) Capital Accumulation, Productivity and Growth in the Israeli Economy. In: Ben-Bassat A (ed) The Israeli Economy, 1985-1998: From Government Intervention to Market Economics, Essays in Memory of Prof. Michael Bruno. MIT Press, Cambridge

Hercowitz Z, Lavi Y, Melnick R (1999) The Impact of macroeconomic Factors on Productivity in Israel, 1960-1996. Bank of Israel Economic Review(72):103-124

Huber P, Landesmann M, Robinson C, Stehrer R (2010) Migrants' Skills and Productivity: A European Perspective. National Institute Economic Review 213:R20-34

Hunt J, Gauthier-Loiselle M (2010) How Much Does Immigration Boost Innovation? American Economic Journal: Macroeconomics 2(2):31-56

Israel Central Bureau of Statistics (1990-1999) (2999) Manufacturing and Crafts Surveys. , Jerusalem, Israel

Jones P (2001) Are Educated Workers Really More Productive? Journal of Development Economics 64(1):57-79

Kangasniemi M, Mas M, Robinson C, Serrano L (2012) The Economic Impact of Migration: Productivity Analysis for Spain and the UK. Journal of Productivity Analysis 38(3):333-43

Katz LF, Summers LH (1989) Industry Rents: Evidence and Implications. Brookings Papers on Economic Activity O(Special Issue):209-275

Lewis EG (2003) Local Open Economies within the U.S.: How Do Industries Respond to Immigration? Federal Reserve Bank of Philadelphia, WP 04-01

Lewis EG (2011) Immigration, Skill Mix, and Capital-Skill Complementarity. Quarterly Journal of Economics 126(2):1029-1069 
Moretti E (2004) Workers' Education, Spillovers and Productivity: Evidence from Plant-Level Production Functions. American Economic Review 94(3):656-690

Olley GS, Pakes A (1996) The Dynamics of Productivity in the Telecommunications Equipment Industry. Econometrica 64(6):1263-1297

Ottaviano G, Peri G (2012) Rethinking the Effect of Immigration on Wages. Journal of the European Economic Association 10(1):152-97

Peri G (2012) The Effect of Immigration on Productivity: Evidence from US States. Review of Economics and Statistics 94(1):348-58

Peri G, Sparber C (2009) Task Specialization, Immigration, and Wages. American Economic Journal: Applied Economics 1(3):135-69

Quispe-Agnoli M, Zavodny M (2002) The Effect of Immigration on Output Mix, Capital and Productivity. Federal Reserve Bank of Atlanta Economic Review 87(1):17-27

Regev H (1993) Longitudinal Panels of Industrial Enterprises in Israel: Construction, Definition and Use in Research. Unpublished manuscript, Israel Central Bureau of Statistics

Weiss Y, Sauer RM, Gotlibovski M (2003) Immigration, Search, and Loss of Skill. Journal of Labor Economics 21(3):557-591

Zavodny M (2011) Immigration and American Jobs."American Enterprise Institute and the Partnership for a New American Economy. Policy study, http://www.aei.org/files/2011/12/14/-immigration-and-americanjobs_144002688962.pdf

doi:10.1186/2193-9039-2-6

Cite this article as: Paserman: Do high-skill immigrants raise productivity? Evidence from Israeli manufacturing firms, 1990-1999. IZA Journal of Migration 2013 2:6.

Submit your manuscript to a SpringerOpen ${ }^{\circ}$ journal and benefit from:

- Convenient online submission

- Rigorous peer review

- Immediate publication on acceptance

- Open access: articles freely available online

- High visibility within the field

- Retaining the copyright to your article

Submit your next manuscript at $\boldsymbol{\sim}$ springeropen.com 